English Language and Linguistics 22.3: 323-355. (C) Cambridge University Press 2017. This is an Open Access article, distributed under the terms of the Creative Commons Attribution licence (http://creativecommons.org/licenses/by/4.0/), which permits unrestricted re-use, distribution, and reproduction in any medium, provided the original work is properly cited. doi:10.1017/S1360674316000459

\title{
The unstoppable glottal: tracking rapid change in an iconic British variable ${ }^{1}$
}

\author{
JENNIFER SMITH \\ University of Glasgow \\ and \\ SOPHIE HOLMES-ELLIOTT \\ University of Southampton \\ (Received 9 September 2015; revised 20 September 2016)
}

\begin{abstract}
This article presents a sociolinguistic investigation of a rapidly expanding innovation in the UK, glottal replacement, in a variety spoken in northeast Scotland. Quantitative analysis of the form shows a dramatic change in apparent time: from a minority variant in the older generation to a full 90 per cent use in the younger generation. Further analysis of the constraints on use provide a detailed snapshot of how this variant moves through social and linguistic space. Males use higher rates of the non-standard form in the older generations but this constraint is neutralised in the younger generations as the form increases. Styleshifting according to interlocutor also neutralises through time. While these results across the social constraints are in line with previous analyses, the linguistic constraints differ in this variety. In contrast to most other varieties, intervocalic contexts such as bottle show high rates of glottal replacement. Moreover, word-internal foot-initial contexts (e.g. sometimes) also frequently allow the non-standard variant, despite this being rare in other dialects. Although glottal replacement is largely considered to be a 'torchbearer' of geographical diffusion, this in-depth analysis suggests that different varieties may have different pathways of change in the rapid transition from [t] to [?] throughout the UK.
\end{abstract}

\section{Introduction}

Research on glottal replacement, ${ }^{2}$ as in $\left(1 \mathrm{a}-\mathrm{f}^{3}\right)$, has demonstrated that it 'is one of the most dramatic, wide-spread and rapid changes to have occurred in British English in recent times' (Trudgill 1999: 136).

1 This work was supported by the Economic and Social Research Council (grant no. ES/K000861/1). We would like to thank the editor of $E L L$ and two anonymous reviewers: their comments greatly improved this paper, although none but ourselves are responsible for its present content. We would also like to thank our speakers in Buckie without whose help this research would not exist.

2 A number of terms are used to describe the variable realisation of / $t$ / in specific contexts including: t-glottalling, glottal stops, glottal replacement, glottalisation (e.g. Milroy et al 1994: 330; Wells 1982: 261). In this article we adopt the term 'glottal replacement', the variable realisation of underlying / $t$ / with an auditorily distinct glottal stop [?], which either masks the oral plosive release or replaces the plosive entirely (see also Schleef 2013: 201; Wells 1982: 65, 261). This is distinct from glottal reinforcement a variant described by Docherty \& Foulkes (1999: 54) as giving 'the auditory impression of a glottal stop reinforcing any of the three voiceless stops /p, t, k/ when they occur between sonorants (e.g. in happy, set off, bacon). These variants are usually labelled "glottalised".

3 All examples are taken from speaker interview data labelled by the speaker's pseudonym and age group. 
(1) (a) One thing about the old post office, you were pre[?]y well ki[t]ed ou[t]. (Jock, older male)

(b) It was be[t]er when we was at school. Aye, it really was be[?]er. (Donald, older male)

(c) He's go[t] it all se[?] up now as well. (Karl, middle-aged male)

(d) I was a bi[?] annoyed a[t] i[?]. (Rose, older female)

(e) Ha[t]ed high school, ha[?]ed it. (Meadow, young female)

(f) A month la[?]er, that's when all the jobs star[?]ed ge[?]ing cu[t]. (Kevin, young male)

Glottal replacement has become ubiquitous in the British Isles in the twentyfirst century, with use attested in the southern counties of England and Wales (e.g. Tollfree 1999; Mees \& Collins 1999; Straw \& Patrick 2007), the north of England (Docherty et al. 1997; Docherty \& Foulkes 1999; Mathisen 1999; Stoddart, Upton \& Widdowson 1999; Llamas 2007; Richards 2008; Hughes et al. 2012; Baranowski \& Turton 2014) and Scotland (Romaine \& Reid 1976; Macaulay 1977, 1991; Reid 1978; Stuart-Smith 1999) including the northeast (Marshall 2001), working-class speakers (Williams \& Kerswill 1999; Flynn 2012) and RP speakers (Fabricius 2000; Tollfree 1999), first language and second language speakers (Drummond 2011; Schleef 2013), and in both casual and careful speech (Stuart-Smith 1999); in both males and females (e.g. Williams \& Kerswill 1999; Mees \& Collins 1999). Glottal replacement may have started as a stereotype of urban speech (e.g. Milroy et al. 1994: 328) but such is its ubiquity that it is fast becoming a stereotype of British speech more generally.

Both the speed and spread of change across the UK have made glottal replacement something of a 'poster child' for studies of language variation. Thus while it might have been the case some twenty years ago that we did not 'as yet have an idea of how [glottal replacement] operate[s] in different dialects in the British Isles' (Milroy et al. 1994: 350), we now have much more information on the processes at work in the rise of this iconic variable. Despite this, some key questions remain surrounding the origins and subsequent development of the variable across time and space. Specifically, 'whilst it would be tempting to view the spread of glottalization in late twentieth century English as a change originating in lower class London English' (Beal 2014: 166), with monogenetic roots spreading outwards to the rest of the UK, the historical record suggests that it may, in fact, have polygenetic roots. For example, in Andrésen's (1968) detailed historical study of the form, he cites Bell (1860) as noting the form in the west of Scotland as far back as the mid nineteenth century and also Sweet's (1908) observation that it occurs at the beginning of the twentieth century in 'some North English and Scotch dialects'. This leads Andrésen (1968: 18) to suggest that glottal replacement first appeared in the west of Scotland, and in particular, Glasgow, and subsequently spread to the east of Scotland and the far north of England some years later. Further south, SED evidence leads Trudgill (1999: 136) to suggest that it spread from Norwich to London and not vice versa. Thus we may have a shared outcome rapid increase in use of [?] across all dialects studied to date in the UK - but one which may arise from different roots. This is exemplified most strikingly by Stuart-Smith's 
(1999: 201) study of glottal replacement in Glasgow where she finds 'two distinct types of allophonic patterning, possibly reflecting the Scots/Scottish Standard English linguistic heritage of working class and middle class speakers respectively'. In other words, the same change via two different sources.

As highlighted by the above, 'satisfactory accounts of the trajectory of the change must take into account its embedding in the local dialects of different regions and the history of those dialects' (Milroy et al. 1994: 350). This may, in turn, elucidate the roots and subsequent development of the change from [t] to [?]. In this article we contribute to our understanding of the trajectory of change through an in-depth analysis of a dialect spoken in the northeast periphery of Scotland, Buckie, an area which is distant both geographically and linguistically from the putative 'home' of glottal replacement in the west of Scotland. By examining the social and linguistic constraints across three generations of speakers, we will be able to shed light on where this variable came from and how and when the innovation took hold. This, in turn, will contribute to our understanding of how this iconic variable spreads across time and space.

\section{Previous research}

While the roots of glottal replacement as gleaned from the historical record may be subject to debate, what is clear is that it is extremely prevalent in the British Isles in the twenty-first century - all varieties studied to date demonstrate a sharp rise in this variant across the generations (e.g. Docherty \& Foulkes 1999: 50; Flynn 2012: 294; Macaulay 1977: 45; Marshall 2001: 54; Mathisen 1999: 110; Stoddart, Upton \& Widdowson 1999: 75; Stuart-Smith 1999: 191). The progression of this variant across the social and linguistic spheres highlights both similarities and differences within and between the varieties studied, as detailed below.

\subsection{Linguistic context}

Perhaps not surprisingly, all studies show that the linguistic contexts in which the variable occurs have a significant influence on variant choice (Docherty et al. 1997: 294; Docherty \& Foulkes 1999: 50; Drummond 2011: 292; Flynn 2012: 292), with a number of key findings emerging from previous research.

The majority of studies show that there are much lower rates of glottal replacement in word-medial, ambisyllabic contexts, as in (2a) and (2b), when compared to wordfinal contexts as in (2c) (e.g. Wells 1997: 19-21; Stuart-Smith 1999: 192; Flynn 2012: 294; Fabricius 2002: 120).

(2) (a) She's growing tatties and athing in her garden. (Moira, older female)

(b) She was just little and she was playing the piano, ken. (Natalie, middle-aged female)

(c) Ken five o'clock in the evening 'til nine o'clock at night. (Rachel, middle-aged female) 
Within codas, three environments are typically compared: pre-consonantal (PreC) as in (3a), pre-vocalic (PreV) (3b) and pre-pausal (PreP) (3c).

(3) (a) And we did na get there 'til like half seven. (Beverley, young female)

(b) Aye we'd a lot of fun at Cullen Bay. (Lainey, middle-aged female)

(c) Oh nah, I've never been to it. (Keifer, young male)

A dominant constraint hierarchy for variable glottal replacement emerges in these coda environments across most studies conducted in more southern areas of the UK: PreC $>$ PreP $>$ PreV. This pattern is attested in London, both for the vernacular and RP (Tollfree 1999: 171), Reading and Milton Keynes (Williams \& Kerswill 1999: 147) and Cardiff (Mees \& Collins 1999: 198). More northern varieties also exhibit this hierarchy: in Nottingham (Flynn 2012: 294), Derby (Docherty \& Foulkes 1999: 50-1), Hull (Williams \& Kerswill 1999: 147) and Sandwell (Mathisen 1999: 115). So widespread is this ordering of constraints that Straw \& Patrick (2007: 390) refer to it as the diffusion pattern, referring to both its geographical spread across different regions and also its spread through the different linguistic environments. This may suggest that glottal replacement is 'diffusing as a package from a London epicenter' (Milroy 2007: 164), but a number of 'regional particularities' are also noted which may point towards a polygenetic root (Schleef 2013: 203). This is particularly the case in Tyneside (Milroy et al. 1994: 341), where the hierarchy is $\mathrm{PreC}>\mathrm{PreV}>\mathrm{V} \_\mathrm{V}>$ PreP, and Scotland, where a number of different hierarchies are reported both between and within the same variety (see Stuart-Smith 1999: 194-5). ${ }^{4}$

\subsection{Social constraints}

A complicated interplay between gender, class and style is evident in previous research (e.g. Stuart-Smith 1999: 194; Fabricius 2000: 141). This interaction is exemplified in the apparently contradictory results for gender: in some communities, males lead the change (Macaulay 1977: 45; Marshall 2001: 54; Kerswill 2003: 230-1), in others, females are in the lead (Mathisen 1999: 17; Kerswill 2003: 230-1; Milroy et al. 1994: $341)$ and others still report no gender difference in the progress of the change (StuartSmith 1999: 199-200; Schleef 2013: 211).

Given that [?] is the stigmatised form, the finding that males lead the change in many varieties is not surprising (e.g. Labov 2001: 293). Trickier to explain is the finding that middle-class females use higher rates of [?] than middle-class males (e.g. Mees 1987 - cited in Mees \& Collins 1999: 192; Watt \& Milroy 1999: 30; Mathisen 1999: 110). These findings have led Milroy et al. (1994: 336-7) and Mees (1987) to suggest that women favour glottal replacement when it is associated with supralocal norms (as opposed to a local variant, as is the case for glottal reinforcement in Tyneside,

${ }^{4}$ In addition to linguistic environment, Schleef (2013: 210) finds a number of other linguistic constraints influence variant choice, including lexical effects and grammatical category. 
for example). Further, a lack of gender differences can be explained by the stage of change, specifically the gender gap neutralizes as glottal replacement increases. This is demonstrated by Stuart-Smith's (1999: 200) real-time comparison of Macaulay and Trevelyan's (1973) findings in Glasgow with her data from the 1990s, where the gender differences demonstrated in earlier stages of the change disappear in the later stages. Thus these apparently contradictory findings for gender are explained through reference to the local status of the variant and the stage of change within that community.

Situational context is further implicated in the rise of this variable, both in terms of the classic sociolinguistic treatment of style and also in terms of the effects of interlocutor. As glottal replacement has been described as one of the 'most heavily stigmatized features of British English' (Milroy et al. 1994: 4) and 'widely regarded as ugly and also a lazy sound' (Wells 1982: 35), it is not surprising that studies often report higher rates of use with more informal styles (Trudgill 1999: 132; StuartSmith 1999: 191). However, in step with its rapid spread, it may have 'gone upmarket' (Fabricius 2002: 124) as it is increasingly diffusing to more formal styles in younger speakers (Stuart-Smith 1999: 199; Marshall 2001: 62). In addition, Trudgill (1986: 8) finds that interlocutors may also play a part in influencing rates of use. ${ }^{5}$ In his study of Norwich (Trudgill 1974) he found that his own rates of glottal replacement correlated with the rates of his interviewee, as demonstrated in figure 1. He suggests that this results from short-term accommodation (e.g. Giles 1973; Coupland 1984), but that such repeated short-term accommodation may in actual fact lead to longterm permanent change: 'If a speaker accommodates frequently enough to a particular accent or dialect, I would go on to argue, then the accommodation may in time become permanent particularly if attitudinal factors are favourable' (Trudgill 1986: 39). We examine the potential for interlocutor accommodation through our study's design (section 4.5) and the implications of this process in the spread and development of this feature (see section 5). Before doing so, we first describe the community from which the data are drawn.

\section{Data and method}

\subsection{The community}

Buckie is a small fishing town situated on the north east coast of Scotland, 60 miles from Aberdeen (see figure 2).

Due to economic independence as a result of the fishing industry, until recently the community was isolated geographically, socially and culturally from more mainstream norms. Thus Buckie is a classic 'relic' area, retaining linguistic forms from the history

\footnotetext{
5 Trudgill (1988: 44) remarks that this finding 'tallies very well with a strong casual impression shared by many older people that younger people in many parts of Britain today no longer feel [?] to be a stigmatised feature to be avoided in certain situations, as older people do'.
} 


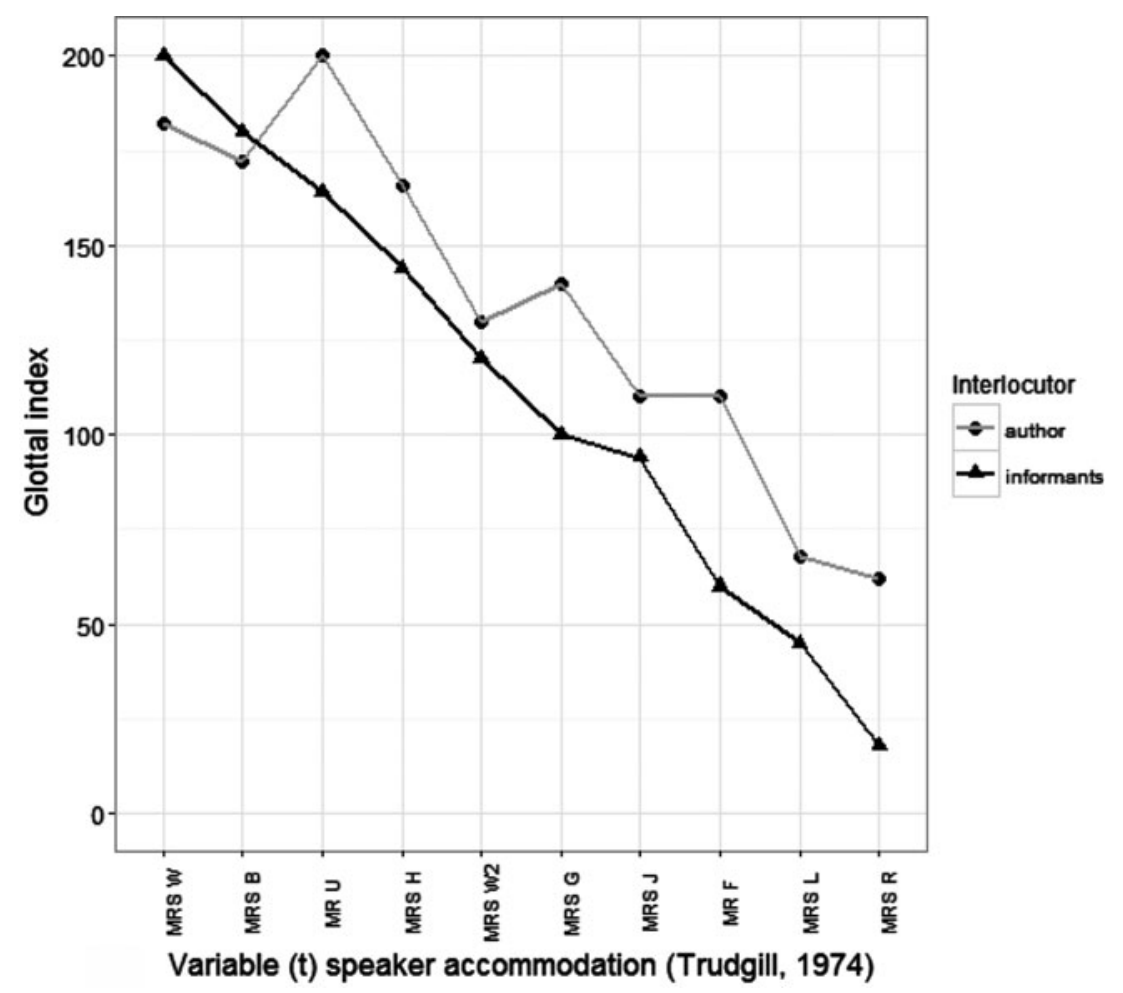

Figure 1. Variable (t) rates by interlocutor (based on data from Trudgill 1974)

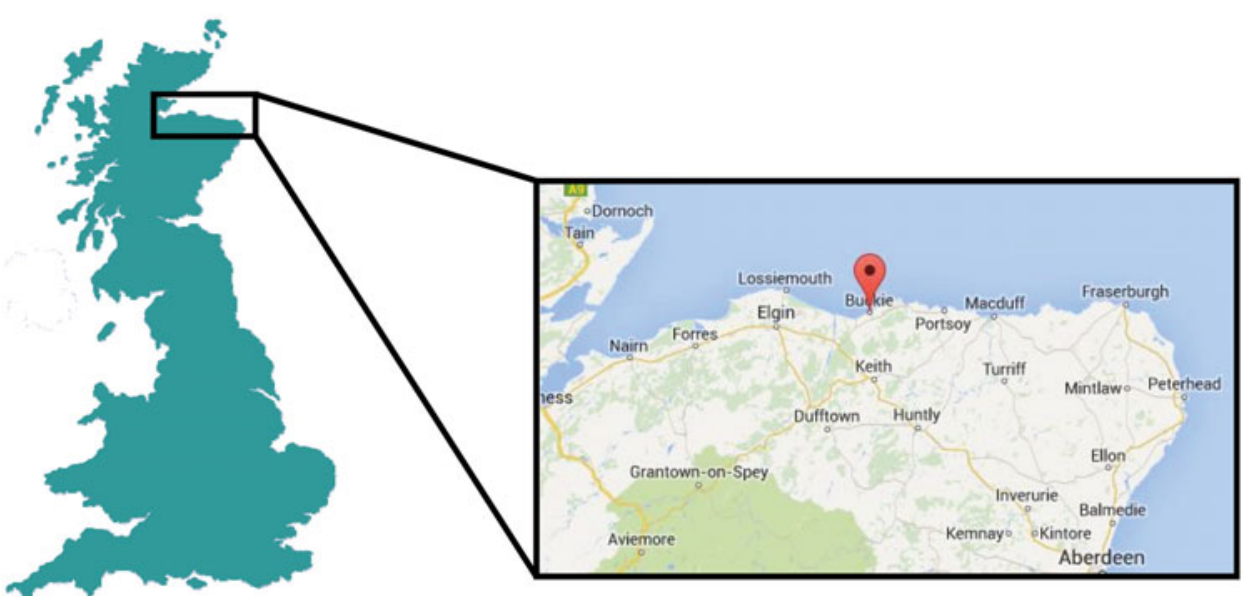

Figure 2. (Colour online) The research site Buckie, Scotland (C Buckie, Moray. Map Data. Google Maps. Google, accessed 5 August 2015) 
Table 1. Sample stratified by age and gender

\begin{tabular}{lcc}
\hline \hline & Male & Female \\
\hline Young (16-18) & 4 & 4 \\
Middle-aged (35-45) & 4 & 4 \\
Older (69+) & 4 & 4 \\
\hline \hline
\end{tabular}

of English that have long disappeared in other more mainstream varieties. For instance, features such as the Northern Subject Rule, unshifted vowels and the voiceless labiovelar approximant $[\mathrm{M}]$ in wh- forms are still in use (Smith 2001a, 2001b, 2004, 2005). Despite this, glottal replacement is pervasive as indicated by a young male's use in (4):

(4) Um, it's if it happens again that's me to[?]ally ou[?] of football like. 'Cause i[?''ll keep happening. If I dinna rush into it too fast and just ge[?] it properly sor[?]ed I should be okay. I had physio and they telt me to stop it 'cause I've got to go back and see the orthopaedic. 'Cause something is not right with my scan, bu[?] I'd say it's go[?]en be[?]er since I s- star[?]ed doing the exercises more regularly, basically building up my quads round about the knee and just strengthen it a wee bi[?]y.

\subsection{The sample}

The sample consists of 24 speakers, stratified by age and gender as shown in table 1, and they were recorded as part of a larger project One Speaker, Two Dialects: Bidialectalism Across the Generations in a Scottish Community (Smith 2013-16). To control the sample as much as possible, participant selection is based on the following criteria: 1. both parents born and raised in the community; 2 . where applicable, spouse from the community; 3 . no more than one year spent away from the community; 4 . no education beyond secondary school level.

The speakers were recorded twice: first with a community 'insider' using classic sociolinguistic interview techniques (Labov 1984) and second with a community 'outsider' to assess the effects of addressee styleshifting (e.g. Bell 1984). This design will enable us to examine in detail questions surrounding the role of situational context in governing use of glottal replacement (see section 4.5). Each interview was fully transcribed using Transcriber (Boudahmane, Manta, Antoine, Galliano \& Barras 2008), creating a speech-to-orthography time-aligned corpus of approximately 1 million words (http://trans.sourceforge.net/en/presentation.php).

\subsection{Analysis}

As the focus of the present study is on the sociolinguistic correlates of glottal replacement rather than on its acoustic profile, we follow the majority of studies in conducting an auditory analysis of forms (see also Trudgill 1974; Macaulay 1977; Mees 1987; Milroy et al. 1994; Mees \& Collins 1999; Mathisen 1999; Stuart-Smith 
1999; Tollfree 1999; Williams \& Kerswill 1999; Marshall 2001; Fabricius 2000; Straw \& Patrick 2007; Llamas 2007; Drummond 2011; Flynn 2012; Schleef 2013; Baranowski \& Turton 2014).

In order to have sufficient data for statistical analysis, we extracted approx. 100 tokens per speaker per insider/outsider interview (200 tokens in total per speaker), starting at ten minutes into the interview to mitigate the Observer's Paradox (see Labov 1972: 209). Ambiguous tokens, i.e. those which were difficult to distinguish auditorily, were discarded from the analysis. These accounted for less than 2 per cent of the overall instances. In accordance with type/token issues (Wolfram 1993: 214), high-frequency items such as get, that, it etc. were capped at ten tokens per speaker interview. Tokens with a following non-sonorant consonant, as in (5a,b), were excluded (see also Macaulay 1991: 33; Stuart-Smith 1999: 188; Flynn 2012: 276), due to the tendency for the $[\mathrm{t}]$ to assimilate to the following consonant (e.g. Holmes 1994: 441; Shockey 2003: 38).

(5) (a) You get it back in an hour. (Adam, middle-aged male)

(b) It's just, you name it, we've got it. (Karl, middle-aged male)

For the remaining data, we took a bottom-up approach, including all other contexts where glottal replacement was observed to occur in the dialect. These included ambisyllabic contexts (6) coda contexts (7), but also onset contexts (8). In the majority of dialects, glottal replacement is generally blocked in onset contexts; this includes both word-initial contexts (take, tear, tiger etc.) and also word-internal foot-initial contexts (attach, attend, guitar, sometimes, tattoo etc.) (e.g. Tollfree 1999: 171). Not surprisingly, glottal replacement is also blocked in word-initial onset contexts in Buckie. However, our analysis of the data revealed that, for word-internal foot onset contexts (e.g. (8)), glottal replacement is permitted within a range of lexical items. ${ }^{6}$ We therefore extended the variable context to include these environments. During the auditory coding, if a particular lexical item showed variable realisation, it was included within the final analysis Categorical items were excluded. As our analysis is limited to the lexical incidence within our specific corpus of data we cannot provide an exhaustive list of every item where this is permitted within the broader dialect (see further detail in sections 4.3 and 5).

(6) With the daugh[?]ers being away fae home and all. (Joel, older male)

(7) But I did na really enjoy i[?], I would na go back. (Lainey, middle-aged female)

(8) Then some[?]imes the detectives used to come up. (Rhona, middle-aged female)

A total of 4,898 tokens were extracted from the data and then coded for a series of linguistic and social constraints in order to provide a detailed account of the patterning of the variable within the Buckie dialect, and to enable comparison with other varieties.

\footnotetext{
6 We henceforth use the label 'onset' to refer to the contexts where glottal replacement is permitted. However, we note that this only refers to word-internal foot-initial onset contexts and not word-initial ones.
} 
Table 2. Overall distribution of all variants

\begin{tabular}{llllll}
\hline \hline & {$[\mathrm{t}]$} & {$[?]$} & {$[\mathrm{t}]$} & {$\left[\mathrm{t}^{\mathrm{h}}\right]$} & {$[\mathrm{r}]$} \\
\hline $\mathrm{N}$ & 1,565 & 3,165 & 141 & 1 & 26 \\
$\%$ & 32 & 64.5 & 2.9 & 0 & 0.5 \\
\hline \hline
\end{tabular}

We first conducted a descriptive exploration of the data, which we used to inform our inferential analysis. In other words, we built the statistical model from the patterns observed in the descriptive data. This process is reflected through our presentation of the results where we begin with an outline of our factor-by-factor analysis of the data followed by multivariate modelling using RBrul (Johnson 2009) in order to test the relative contributions of these factors to the overall variability.

\section{Results}

\subsection{Overall distributions}

As noted in previous studies (e.g. Stuart-Smith 1999: 188; Straw \& Patrick 2007: 395; Docherty et al. 1997: 293), a number of different variants can exist in the continuum between [ $\mathrm{t}$ ] and [?]. In our data we identified five variants: [t] alveolar stop with full plosive release (9a); [?] glottal stop (9b); [t] variant with alveolar contact but no oral plosive release $(9 \mathrm{c})$; [ $\left.\mathrm{t}^{\mathrm{h}}\right]$ alveolar contact with strongly marked aspirated release $(9 \mathrm{~d})$, [r] voiced alveolar tap (9e):

(9) (a) First drink I ever had was a bo[t]le of hooch. (Neil, young male)

(b) Every Sa[?]urday night and every Monday night, (Jock, older male)

(c) The women all gu[t] $]$ ing fish down there but, (Owen, older male)

(d) We dumped the whole lo[ $\left.\mathbf{t}^{\mathbf{h}}\right]$. (Karl, middle-aged male)

(e) Like for[r]y odd pound each for one ticket. (Meadow, young female)

Table 2 shows the overall distribution of these variants, where a full 97 per cent of the data are either [t] or [?], with the remaining variants used very rarely at all. For this reason, we exclude the minority variants and concentrate on a binary distinction between [t] and [?] (see also Drummond 2011; Fabricius 2000, 2002; Straw \& Patrick 2007).

We now examine a series of factors which have been shown to have an important effect on glottal replacement in other varieties: age (as in generational change), linguistic context, gender and situational context. We first turn to the crucial question of change in apparent time.

\subsection{Change in apparent time}

As indicated in section 2, where data from different generations exist, all studies show an increase in the use of glottal replacement from one generation to the next 


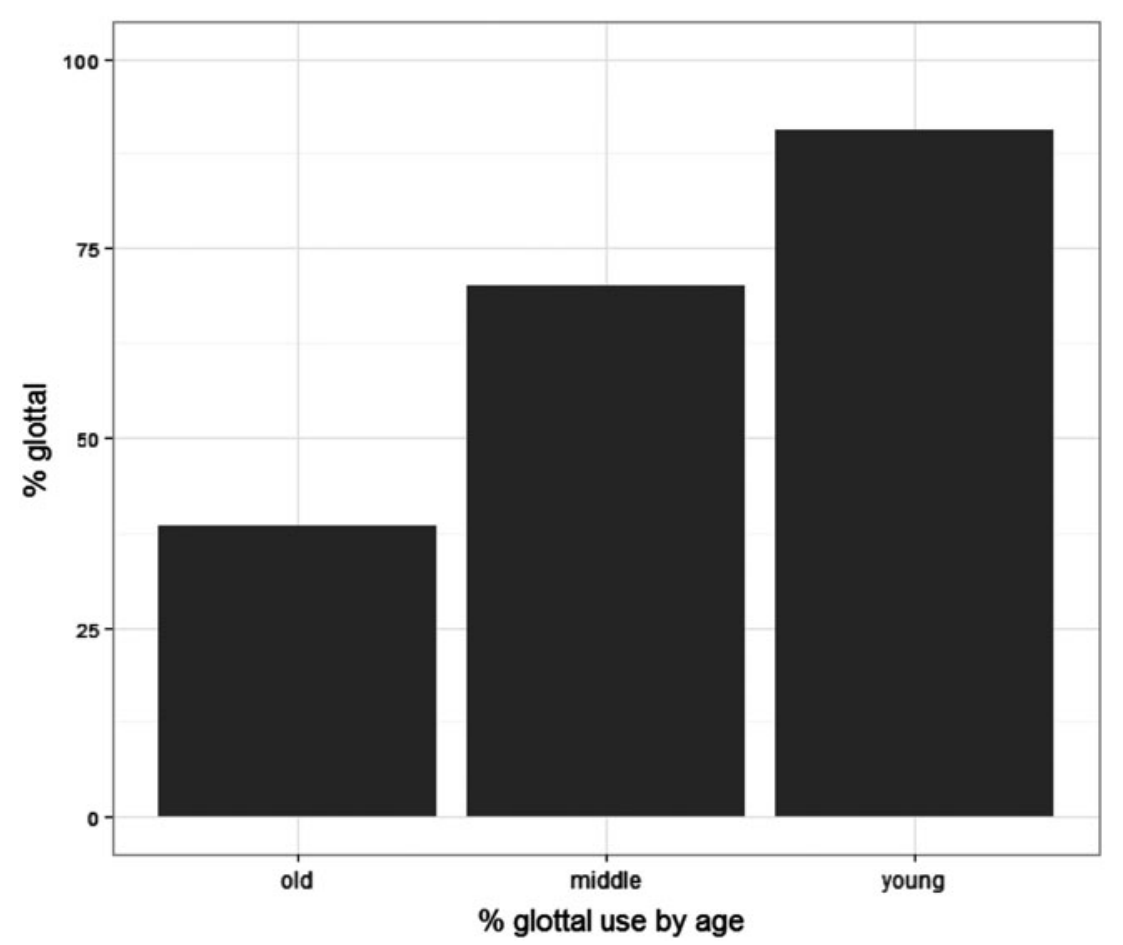

Figure 3. Overall distribution of [?] by age

(e.g. Docherty \& Foulkes 1999: 50; Flynn 2012: 294; Macaulay 1977: 45; Marshall 2001: 54; Mathisen 1999: 110; Stoddart, Upton \& Widdowson 1999: 75; Stuart-Smith 1999: 191). Figure 3 shows the use of glottal replacement across the three different age cohorts in Buckie and shows a dramatic increase across the three generations from 38 per cent in the older speakers, to 70 per cent in the middle-aged and a full 90 per cent in the younger speakers. Our initial observation - that glottal replacement is moving fast in this dialect - is fully borne out here.

While the effects of individual variation will be controlled for by entering speaker into the mixed-effects model as a random factor, it is instructive to first inspect these patterns at a descriptive level (e.g. Guy 1980) to see if all speakers are participating in this fast-moving change. Figure 4 shows the individual rates of variability, where we order the speakers from low to high across each age cohort. The figure shows that all speakers exhibit variable use of glottal replacement. Moreover, interspeaker variability decreases across the generations. For instance, within the older cohort, the range of highest (Donald -78 per cent) to lowest-rate user (Moira -12 per cent) is 66 per cent. This is compared to the middle-aged, which has a range of 44 per cent (Alex - 86 per cent; Lana -42 per cent), and the young cohort, which has a range of 24 per cent (Keifer - 98 per cent; Meadow - 74 per cent). These results suggest 


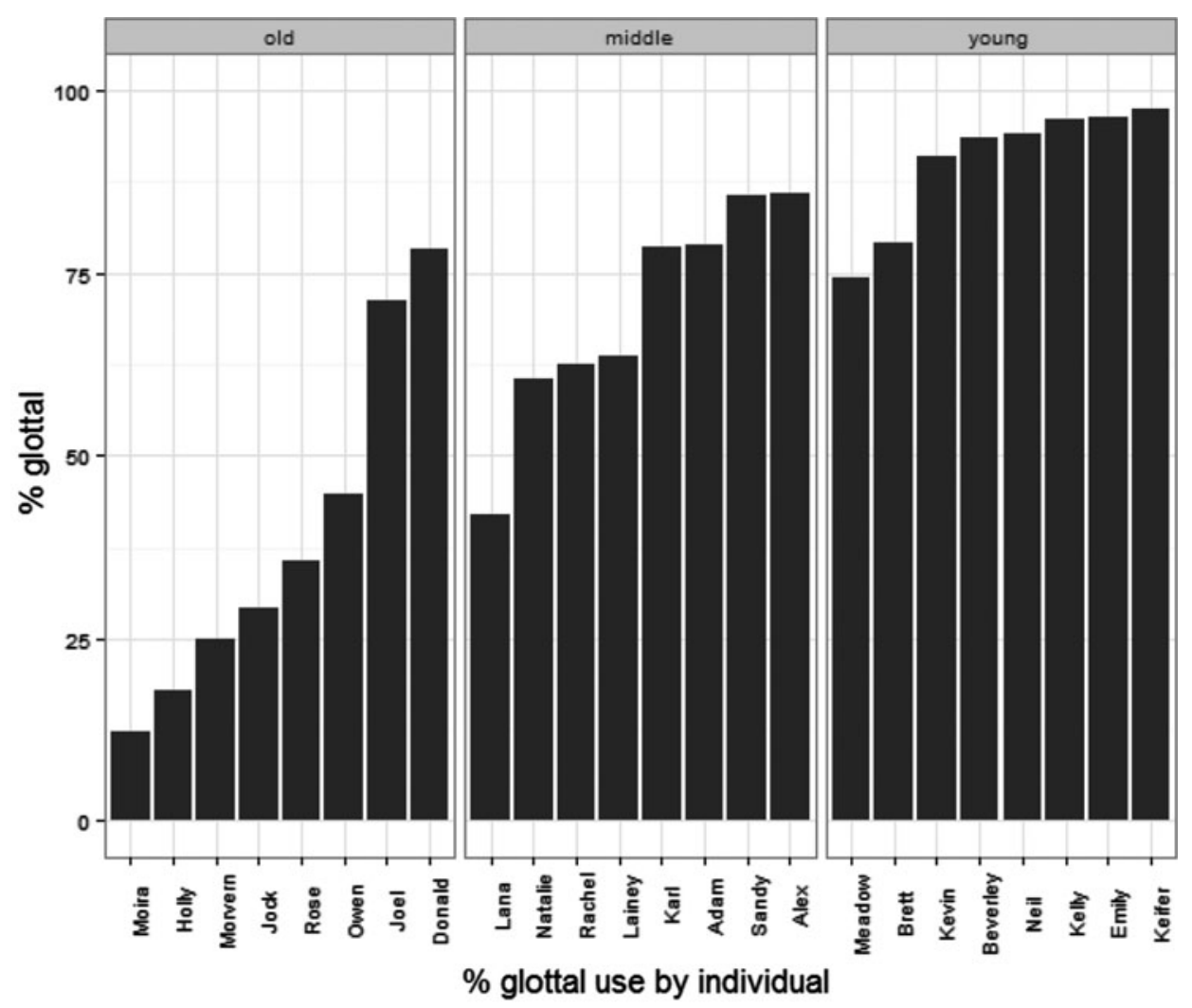

Figure 4. Glottal replacement by individual speaker

that as glottal replacement increases everyone in the community participates in the change.

The above results indicate that despite being a classic relic area, Buckie looks just like all other dialects that have been studied to date, with a rapid rise in use of the non-standard form and all individuals participating in this change. Note too that two of the older speakers, Joel (71) and Donald (69), show very high rates - around 70 per cent of the time. This suggests that glottal replacement has been used in this peripheral geographic location for a number of generations. We return to the question of just how long glottal replacement has been present in the Buckie dialect in our discussion of its origins and development in section 5 .

While the above shows how much speakers use [?], we now turn to the question of where they use it, as this will be crucial in establishing similarities and differences with other dialects and help to inform the trajectory of change. 
Table 3. Linguistic context by syllabic position and following phonetic environment

\begin{tabular}{lcll}
\hline \hline Syllabic position & Following phonetic environment & \multicolumn{1}{c}{ Example } & Description \\
\hline Coda & pause & I like that. & Coda\#Pause \\
& vowel & I like that example. & Coda\#Vowel \\
Ambi & syllabic consonant & bottle, bitten & Ambi\#Sy \\
& vowel & pretty, computer & Ambi\#V \\
Onset & vowel & sometimes, nineteen & Onset \\
\hline \hline
\end{tabular}

\subsection{Linguistic constraints}

As detailed in section 2.1, the linguistic patterning of glottal replacement differs across varieties. Both following phonetic context (Docherty \& Foulkes 1999: 50-1; Tollfree 1999: 171; Williams \& Kerswill 1999: 147; Flynn 2012: 294; Straw \& Patrick 2007: 164) and word position (e.g. Wells 1997: 19-20; Stuart-Smith 1999: 192; Fabricius 2002: 120; Flynn 2012: 294) play a part in governing the variation. In order to capture the important interactions between syllabic position and following phonetic environment, and to account for the full variable context in the current data, we combined syllabic context and following environment within one elaborated category. This resulted in a total of 21 different contexts of use, as detailed in the table A1 in the Appendix. Although these categories provide a detailed descriptive analysis of the possible contexts for glottal replacement in Buckie, they are unwieldy in terms of statistical analysis. Further investigation of these 21 forms revealed a broader set of five categories as shown in table 3. Specifically, for coda contexts we follow previous analyses in dividing the data into Coda\#Pause and Coda\#Vowel (Coda\#Consonant contexts are excluded - see section 3.3). For ambisyllabic contexts, we further divide the data into whether there was a following consonant or vowel. Finally, we include a range of syllable word-internal foot-onset contexts.

Figure 5 shows the results when the data are divided by linguistic context and reveals the following more to less hierarchy of use of [?]: Ambi\#Syl consonant $($ bottle $)>$ Coda\#Vowel $($ that is $)>$ Ambi\#Vowel (pretty) $>$ Coda\#Pause (I like that.) $>$ onset (sometimes). Where comparison is possible, this hierarchy looks very different to other varieties, both quantitatively and qualitatively. For example, note the high rates of the non-standard variant in ambisyllabic contexts - previous research shows that this context is highly disfavoured in other varieties (e.g. Flynn 2012: 294; Stuart-Smith 1999: 198) - and the robust use of [?] in onset positions, where many other dialects show only marginal use in this context. We return to these points in section 5 .

\footnotetext{
7 We also included in this category contexts such as biting. This is due to the fact that, in our data, alveolar realisation of variable $<$ ing $>$ is near categorical, as is the case in most varieties of Scots. However, all potential variable tokens were auditorily checked and coded accordingly.
} 


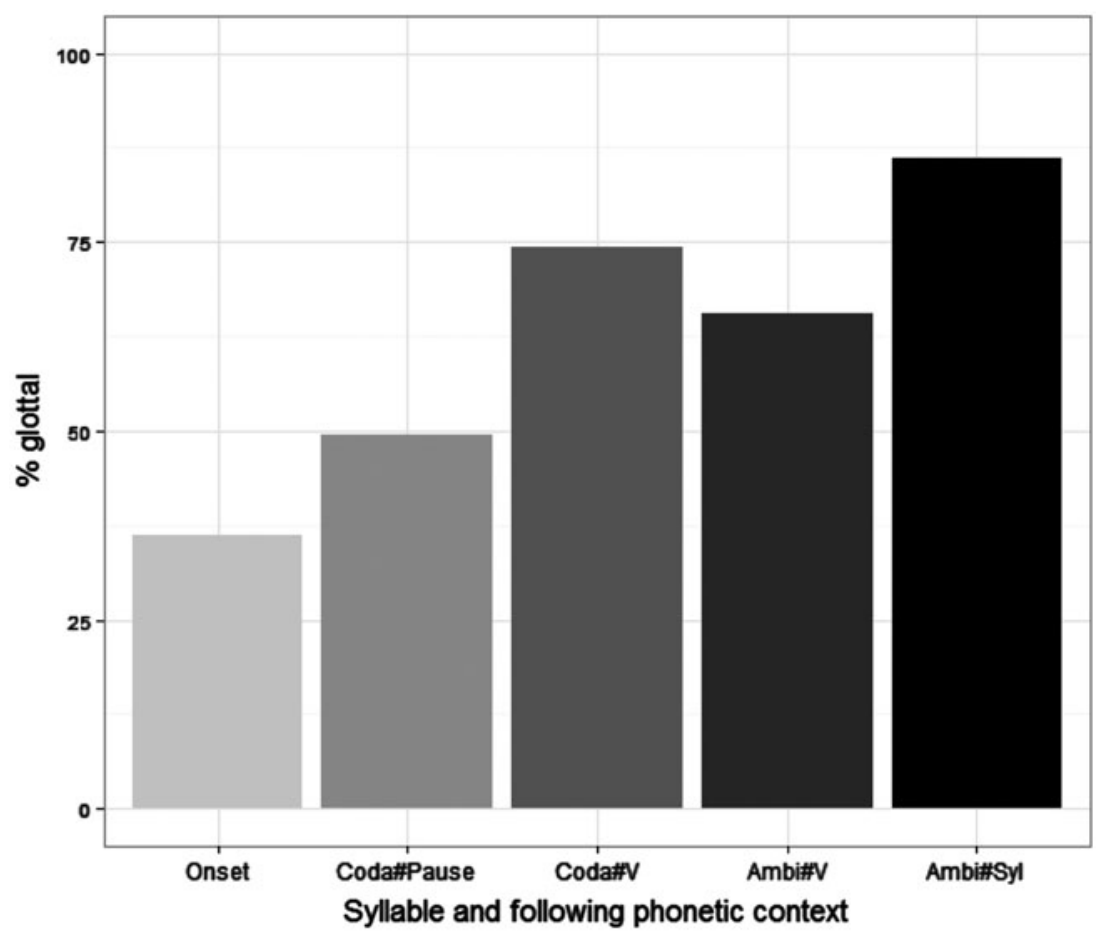

Figure 5. Glottal replacement by syllable type and following phonetic context

How does this relatively unusual overall pattern travel across the linguistic system as [?] becomes the dominant realisation of / $t$ / within the variable context? Specifically, is this constraint hierarchy replicated across each of the generations or is there disruption of constraints in the move from minority to majority variant? In his Nottingham data, Flynn (2012: 294) shows that while the rates of glottal replacement increased, the constraints remained the same. Stuart-Smith (1999: 198), on the other hand, finds both maintenance and reorganisation of constraints: the working-class speakers 'show a systematic allophonic patterning in T-glottalling, which is being maintained by younger speakers', but within the middle-class speakers, the youngest cohort shows a disruption of constraints and a move towards the more working-class patterns. Figure 6 shows the results by linguistic context across the three generations of speakers in Buckie and reveals that nearly every linguistic context increases across the age groups. Between the generations, there are a number of similarities in the linguistic patterning: the Ambi\#Syl context exhibits high levels of the non-standard variant, while the Onset and Coda\#Pause environments exhibit lower rates. However, there are some differences in the exact ordering between the different contexts of use which may indicate the developing profile of the change. In the wider comparison with other varieties, the differences are evident across all generations e.g. in the high use of ambi-syllabic contexts. We examine whether these findings are statistically significant 


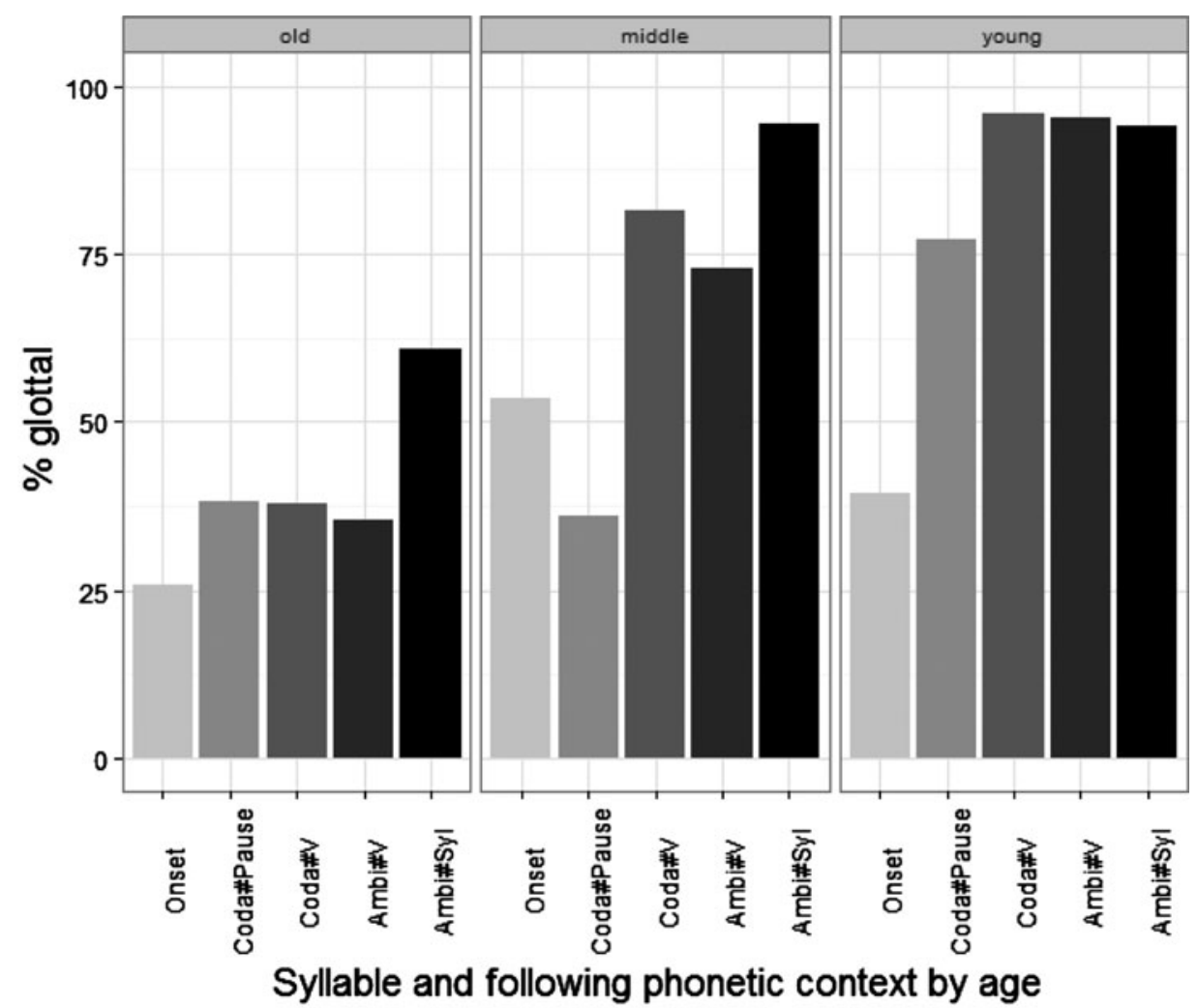

Figure 6. Glottal replacement by age and linguistic context

in section 4.6 and what they may signal for the development of this feature in the community, and more generally in section $5 .{ }^{8}$

In addition to linguistic constraints, integral to the spread of a form is its social evaluation within the community, and a number of social influences are reported in the rise of [?]. We turn now to an examination of the role of social factors in the patterning and development of this feature in Buckie, and how these map onto previous findings.

\subsection{Social constraints}

As detailed in section 2.2, age, class, gender and style have a significant effect on the use of [?]. We cannot test for the effect of class in these data, as our sample comes from working-class speakers only, but we can test for the remaining constraints. We start with gender and pose two questions arising from previous literature: (i) are the males in

\footnotetext{
8 In addition to linguistic context, we examined a number of other factors such as grammatical category (see e.g. Schleef 2013). We report here only those linguistic factors which were statistically significant.
} 


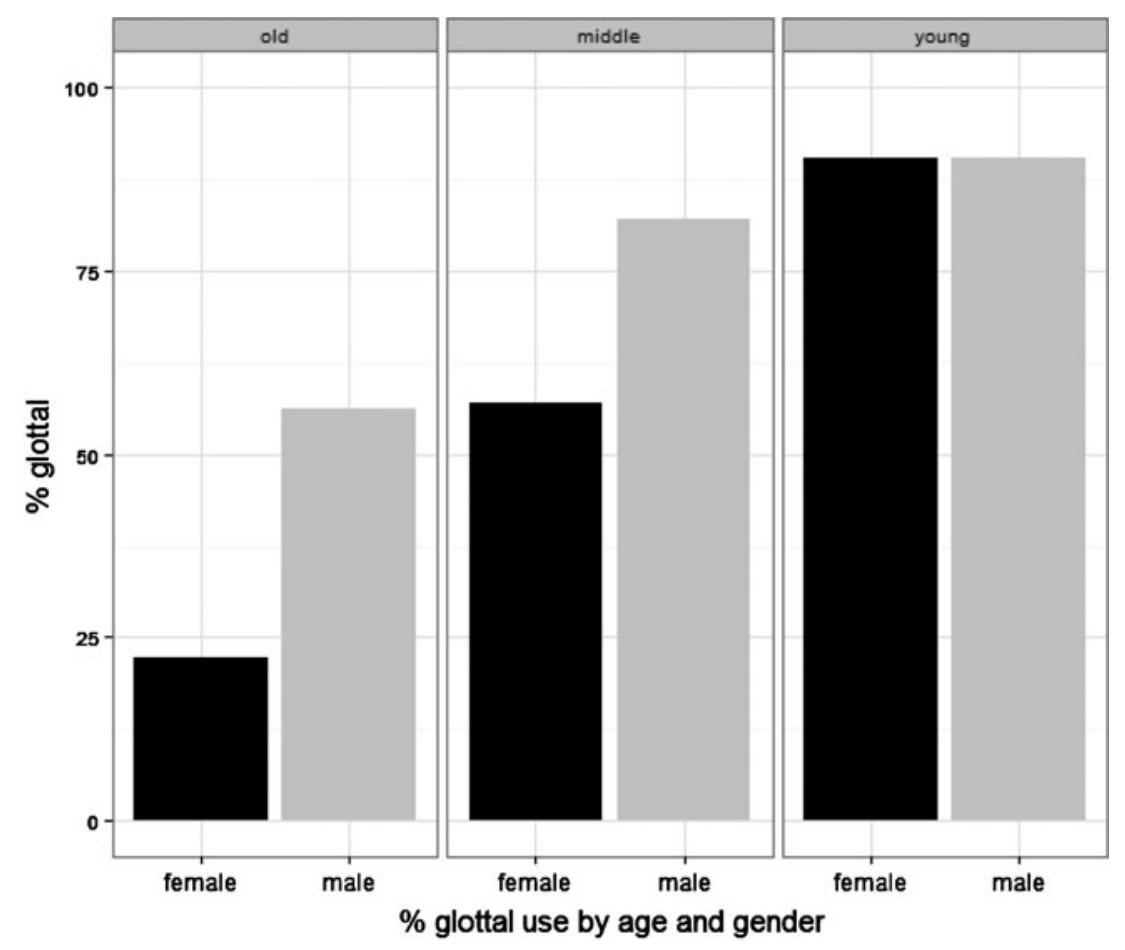

Figure 7. Glottal replacement by age and gender

this working-class community leading the change as previous research has found, and (ii) is the gender effect neutralised as glottal replacement rises through the generations?

Figure 7 shows that both older and middle-aged speakers have a marked difference in their rates of [?] according to gender. In line with previous research (Docherty \& Foulkes 1999: 161; Kerswill 2003: 232), the working-class males use higher rates of the non-standard form. However, as the change progresses, the gender differences neutralise, as indicated by the matching rates of glottal replacement between the young males and females. In short, the patterns in the Buckie data replicate those found in other studies: males $>$ females and neutralization of gender differences in the progression of change from one variant to another. We will formally test these descriptive statistics in the interaction of age and gender in our multivariate analysis in section 4.6.

\subsection{Situational context}

Recall the findings for style, where glottal replacement has higher rates in informal style, but is increasingly diffusing to more formal styles (Mees \& Collins 1999: 192; Trudgill 1999: 132). As such it is said to be losing its stigma, especially among younger 


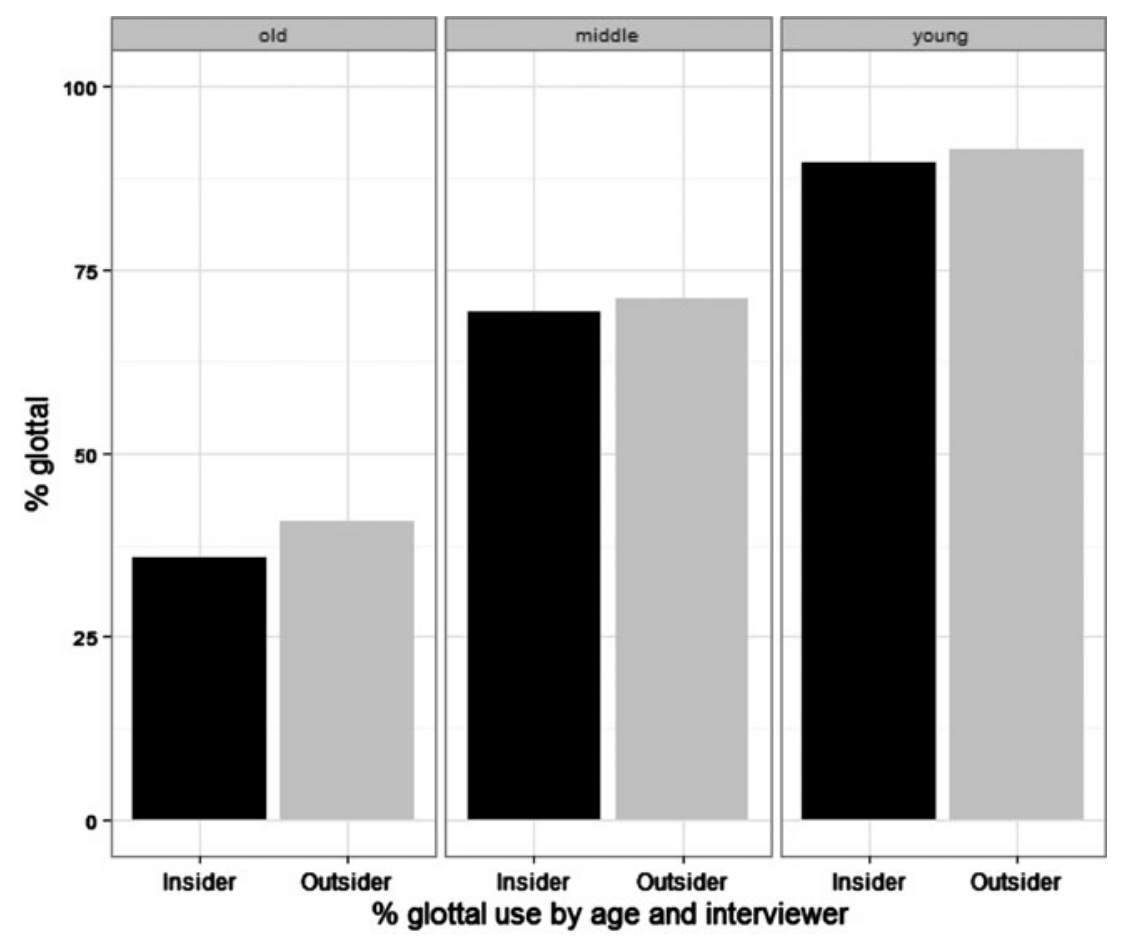

Figure 8. Glottal replacement by age and interviewer

speakers. In the current analysis we do not have data which can test for style through formality in any direct way such as e.g. reading lists. What we do have, however, are data with different addressees: each participant was recorded with both a community insider and a community outsider (see section 3.2). The effect of addressee is well attested in sociolinguistic research (e.g. Bell 1984). More specifically for the present research, Douglas-Cowie (1978) finds that speakers 'code-switch' to more standard variants when talking to a community 'outsider'. Our own ongoing analyses indicate that when speakers in Buckie are in conversation with the community outsider, there is a shift to standard variants only with variables which are socially salient and/or stigmatised in the community (Smith \& Holmes-Elliott 2015). Given the traditional stigmatisation of glottal replacement, we might expect speakers to use lower rates of the glottal variant when in conversation with the community outsider.

To test the effects of addressee with this variable, figure 8 shows the use of [?] by insider and outsider across the different age cohorts. The results demonstrate a slight difference according to addressee for the older speakers, but virtually no difference in the middle-aged or young speakers. Note too that for the older speakers, there are higher rates of [?] when talking to the outsider. This is in stark contrast to DouglasCowie (1978) and our own findings for other socially salient variables, where the 


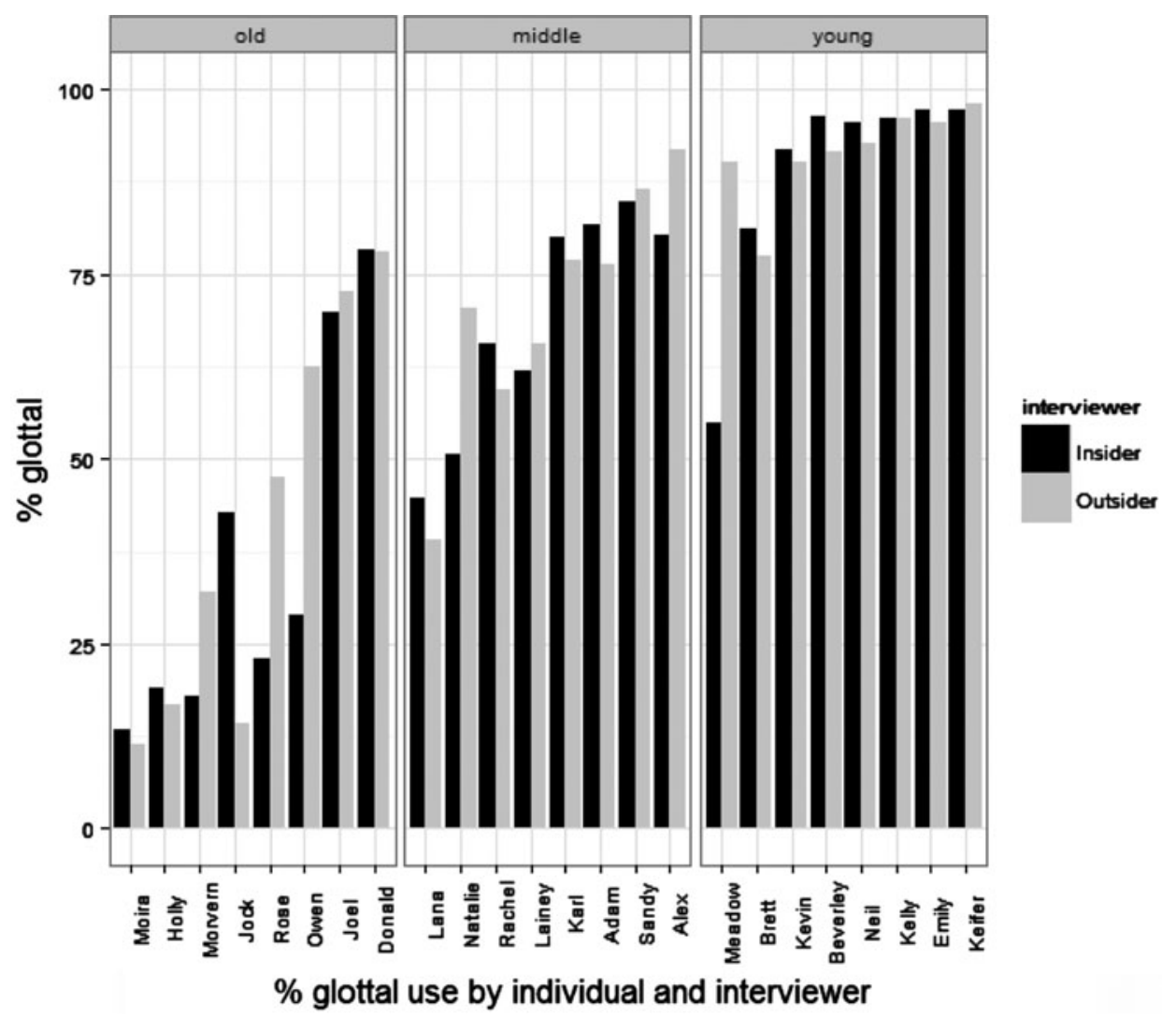

Figure 9. Glottal replacement by individual speaker and interviewer

non-standard variant decreases in conversation with a community outsider. This pattern is further elaborated in figure 9, which shows addressee effect by individual speaker and reveals that the interviewer effects across individuals echo the aggregate effects but here we can see more subtle differences across the individuals. For the older cohort, four speakers have a sizeable difference between insider and outsider Morven, Jock, Rose and Owen - with three of these four using higher rates of [?] with the outsider. Thus only one speaker, Jock, shows the predicted direction - lower rates of the non-standard form with the community outsider. For the middle-aged speakers, there are less stark differences between insider/outsider, and for the younger, only one speaker - Meadow - shows any difference, with much higher rates when talking to the community outsider. Note that this speaker has the lowest rates of use in the younger cohort when talking to the community insider.

Linguistic context may also be sensitive to situational context, and the interaction of these factors may provide further clues to the differing rates of use as shown in figure 9. Previous research shows that particular linguistic contexts are more likely to 


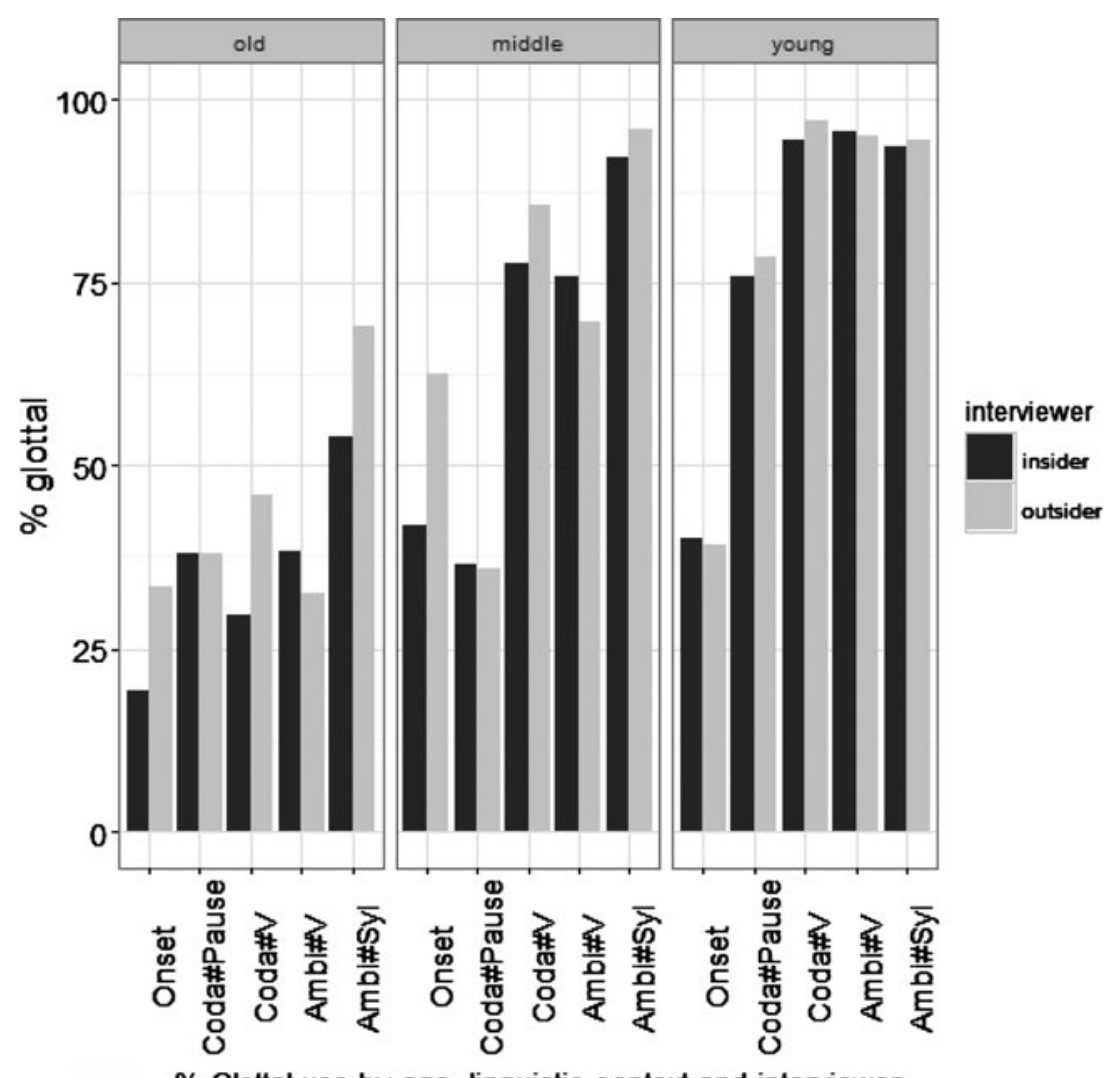

$\%$ Glottal use by age, linguistic context and interviewer

Figure 10. Glottal replacement by age, linguistic context and interviewer

styleshift than others. For instance, in her study of RP, Fabricius (2002: 125) found that Coda\#Pause and Coda\#Vowel contexts showed marked styleshifting towards the standard realisation in more formal speech registers while Coda\#Consonant contexts showed much less styleshifting. ${ }^{9}$ These production results were mirrored by those from perceptual tests: speakers were more likely to rate glottal replacement negatively when it occurred before a vowel or a pause compared to pre-consonantal instances (Fabricius 2002: 132).

In order to examine the intersection of addressee and linguistic environment in these data, we cross-tabulated these factors across the three generations. These results are shown in figure 10.

\footnotetext{
9 As noted in section 3.3, we do not include Coda\#Consonant contexts in these data.
} 


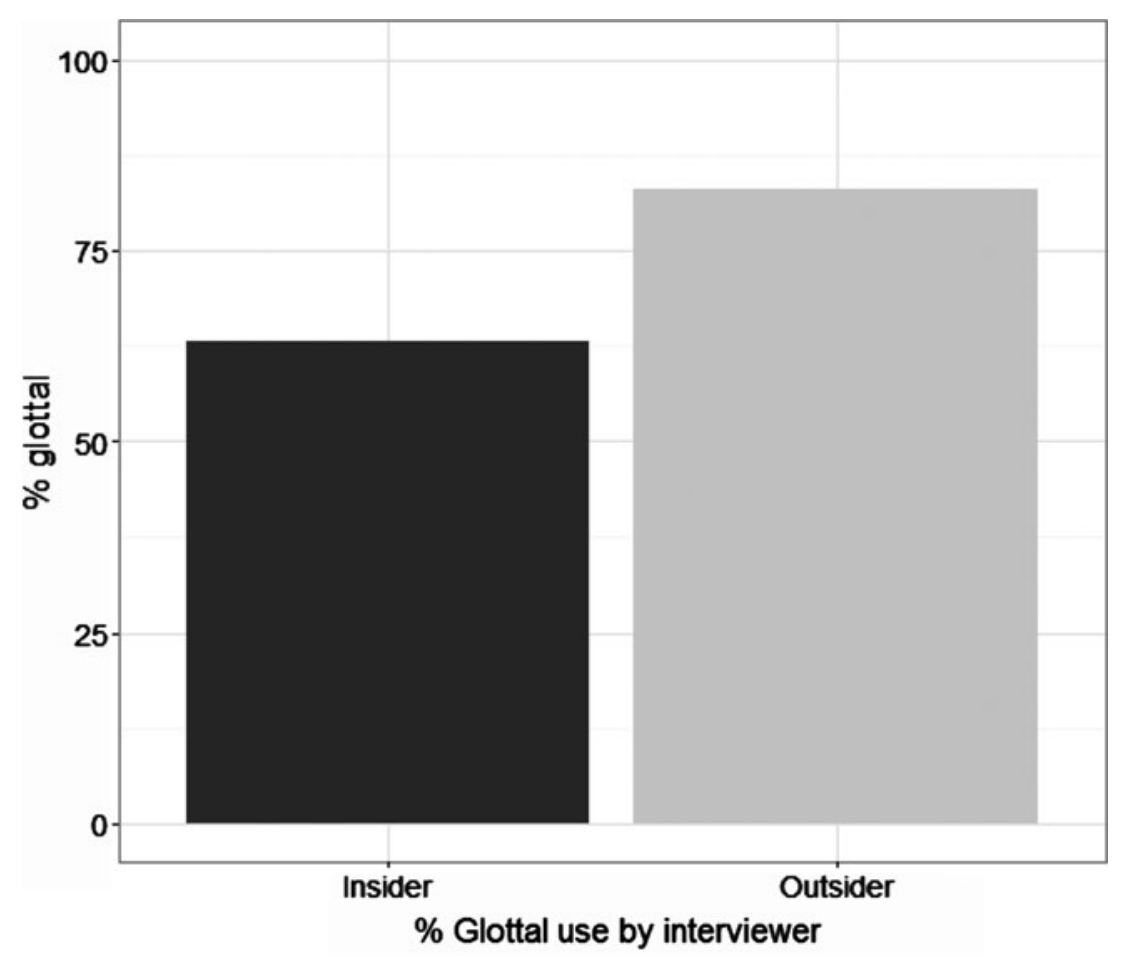

Figure 11. Overall rates of glottal replacement by interviewer

Figure 10 shows that onset contexts in the middle-aged and older speakers have higher rates with the outsider, but we note that these contexts have small Ns, ${ }^{10}$ which precludes any strong conclusion based on this result. Aside from this, all contexts are in fact equal. These findings suggest that addressee does not interact with linguistic context. However, the question remains as to why some speakers show higher rates when they talk to the outsider. Recall Trudgill's findings that glottal replacement was correlated with addressee rates, and he hypothesised that this arose from accommodation (see section 2.2). To test for this possibility here, we examined the rates of glottal replacement in the two interviewers: the community insider and outsider. Figure 11 shows that the overall rates of glottal replacement are indeed higher in the speech of the outsider than the insider, thus there may be an effect of addressee in these data where speakers accommodate to the higher glottal replacement user. We return to why this might be the case in section 5 .

In sum, for linguistic and social constraints on use of [?] for / $t /$, the data demonstrate that:

\footnotetext{
${ }^{10}$ Order: insider $\mathrm{N}=31$, outsider $\mathrm{N}=27$; middle-aged: insider $\mathrm{N}=12$, outsider $\mathrm{N}=16$; younger: insider $\mathrm{N}=15$, outsider $\mathrm{N}=23$.
} 
1. There is rapid change in apparent time - from 38 to 90 per cent in the space of three generations.

2. Linguistic conditioning interacts with age, with differing ordering of constraints across the generations.

3. Gender effects were present in the older and middle-aged cohorts but these differences levelled within the young cohort.

4. There was some evidence of accommodation to interlocutor, particularly in the older cohort but not in any particular linguistic context.

Having examined each of the possible conditioning factors on glottal replacement age, linguistic context, gender and interlocutor - we now model these using the mixed effects multivariate analysis program RBrul (Johnson 2009). Section 4.6 below details our procedure and our results.

\subsection{Multivariate analysis}

Our descriptive results present a number of observations that are relevant in the construction of our models. First, the aggregate results in apparent time demonstrated a rapid change across the generations, in other words a vigorous change in progress. Second, the descriptive statistics suggested that each of the linguistic and social factors interacted with age. For instance, the linguistic conditioning showed differences in the ordering of contexts between the generations, and for the social factors there appeared to be a levelling of constraints over time. To test the interaction between age and the linguistic and social factors more rigorously, we conducted our multivariate analysis using a series of models. First, we modelled all three generations together. In order to formally test the interaction of age and the other constraints, age was entered as an interaction term with each of the other factors: linguistic context, gender and interviewer. The model revealed that age interacts significantly with linguistic context $(\mathrm{p}<.001)$, which demonstrates that the hierarchies are significantly different across the generations. ${ }^{11}$ Gender and interviewer were also shown to significantly constrain the variability as main effects and males showed significantly higher rates of glottal replacement than females; speakers used significantly higher rates of glottal replacement when talking to the outsider. To investigate the details of these interactions more closely, we then modelled the data separately for each age cohort.

The results from these three models are shown in table 4, and these confirm the patterns visible in the by-factor analysis. First, linguistic context is highly significant for every age cohort. Moreover, the constraint hierarchy for each age cohort is different, as indicated through the more-to-less ordering of the log likelihoods for

\footnotetext{
${ }^{11}$ Further, chi-square tests of independence (Fisher's) revealed a highly significant association between age and rates of glottal replacement $\chi^{2}(2)=54.3, p=<.001, \mathrm{~N}=4730$. This indicates that the observed change in rates of glottal replacement across the generations is statistically significant.
} 
Table 4. Mixed-effects logistic regression model of glottal replacement by age cohort

\begin{tabular}{|c|c|c|c|c|c|c|c|}
\hline \multirow[t]{2}{*}{ Factor } & \multicolumn{3}{|c|}{ Older } & \multicolumn{2}{|c|}{ Middle-aged } & \multicolumn{2}{|c|}{ Young } \\
\hline & hierarchy & Log. odds & $\mathrm{N}$ & Log. odds & $\mathrm{N}$ & Log. odds & $\mathrm{N}$ \\
\hline \multirow{6}{*}{$\begin{array}{l}\text { Linguistic } \\
\text { context }\end{array}$} & Ambi\#Syl & 1.2 & 123 & 2.01 & 175 & 1 & 214 \\
\hline & Coda\#Vowel & -.21 & 496 & .7 & 618 & 1.4 & 636 \\
\hline & Ambi\#Vowel & -.23 & 522 & .17 & 426 & 1.3 & 424 \\
\hline & Coda\#Pause & -.02 & 321 & -1.7 & 347 & -.63 & 304 \\
\hline & Onset & -.62 & 58 & -1.24 & 28 & -3 & 38 \\
\hline & $\mathrm{P}<.001$ & & & $\mathrm{P}<.001$ & & $\mathrm{P}<.001$ & \\
\hline \multirow[t]{3}{*}{ Gender } & Male & .84 & 723 & .82 & 833 & n.s. & \\
\hline & Female & -.84 & 797 & -.82 & 761 & n.s. & \\
\hline & $\mathrm{P}<.01$ & & & $\mathrm{P}<.001$ & & & \\
\hline \multirow[t]{2}{*}{ Interview } & Outside & .15 & 763 & n.s. & & n.s. & \\
\hline & $\begin{array}{l}\text { Insider } \\
\mathrm{P}<.05\end{array}$ & -.15 & 757 & n.s. & & n.s. & \\
\hline Deviance & & 1662.98 & & 1495.92 & & 769.31 & \\
\hline Df & & 8 & & 7 & & 6 & \\
\hline Intercept & & -.42 & & .97 & & 2.2 & \\
\hline Mean & & .38 & & .7 & & .9 & \\
\hline
\end{tabular}

each category:

Older: $\quad$ Ambi\#Syl $>$ Coda\#Vowel $>$ Ambi\#Vowel $>$ Coda\#Pause $>$ Onset

Middle-aged: $\quad$ Ambi\#Syl $>$ Coda\#Vowel $>$ Ambi\#Vowel $>$ Onset $>$ Coda\#Pause

Young: $\quad$ Coda\#Vowel $>$ Ambi\#Vowel $>$ Ambi\#Syl $>$ Coda\#Pause $>$ Onset

However, while there are differences in the detail, for each generation a two-way split is visible in the data: the Ambi\#Syl, Coda\#Vowel and Ambi\#Vowel contexts show higher rates of glottal replacement, while Coda\#Pause and Onset contexts have lower rates.

For the social constraints, the models also support the patterns visible in the descriptive results - a general levelling of the constraints. Males significantly favour the change in the older and middle-aged cohorts $(\mathrm{p}<.01$ and $\mathrm{p}<.001)$, but gender does not significantly constrain the variation in the young cohort. The effect of interviewer is only significant for the older cohort, where speakers show significantly higher rates of glottal replacement when talking to the community outsider. Neither middle-aged nor young speakers showed any effect of interlocutor in these two contexts of use.

\section{Discussion}

In the Introduction we suggested that a rapid rise in an iconic British variable in one community could provide a window on key processes in the trajectory of [t] to [?]. To 
uncover these processes, we conducted a series of analyses across social and linguistic constraints in order to shed light on where glottal replacement came from and where it was going.

A key issue is when and where glottal replacement is first attested, and when and where it subsequently spread. As indicated in section 1, the historical record suggests that glottal replacement has a long history in Scotland (e.g. Wright 1905; Andrésen 1968). Our results across apparent time showed that the rapid increase in glottal replacement is a relatively recent phenomenon in Buckie: compare 38 per cent overall in the oldest cohort to 90 per cent in the youngest cohort. However, the fact that the oldest generation used the form 38 per cent of the time overall suggests that this variant has been in Buckie for a number of generations. This time depth is given further support from the analysis by individual speakers: all speakers in the older cohort use glottal replacement. Further, two older males - Joel and Donald, both born in the 1940s - use the form over 70 per cent of the time. ${ }^{12}$ As glottal replacement is said to have existed in the Glasgow area for at least 150 years (Andrésen 1968: 18), the apparenttime analysis from this most peripheral of dialects suggests that it has been widespread for a significant time elsewhere in Scotland also.

In addition to time-stamping the spread of this form, key to the question of the origins of glottal replacement is where in the linguistic system it appears in different varieties. In our analysis we provided a detailed breakdown of the different linguistic contexts of use. Although there were differences in detail in hierarchies of use across the three generations, perhaps due to the ongoing change in this variety, a two-way split was evident in all three generations: Ambi\#Syllabic-consonant (bottle), Coda\#Vowel (that is), Ambi\#Vowel (better) showed greater use of [?] than both Coda\#Pause (right) and onset (sometimes) environments. This linguistic conditioning looks quite different from other more southern dialects, where a PreC $>$ PreP $>$ PreV $>$ V_V hierarchy predominates. Even in Glasgow, another Scots variety, Ambi\#Syllabic contexts show the lowest rates (Stuart-Smith 1999: 194-5). Why might this be the case? As with many other linguistic variables, the historical record may provide further evidence for the initiation and spread of [?]. Wright (1905: 29) states that in west-mid Scotland, Lothian and Edinburgh, 'intervocalic $\mathrm{t}(\mathrm{tt})$ with 1 or $\mathrm{r}$ in the next syllable has become the glottal catch'. The linguistic environment that Wright singles out for glottal replacement may simply be the one that was most salient to his ear, but it is interesting that it includes a context that has the highest rates of use in the older and middle-aged speakers in these data (e.g. bottle). This suggests that this environment was the original entry point for glottal replacement in this dialect, with subsequent spread to other environments as the variant increased in use. ${ }^{13}$ Thus glottal replacement in Buckie may not be the result of the spread of supralocal norms in the 'diffusionist model' (Straw \& Patrick 2007:

${ }^{12}$ We note that this apparent-time analysis cannot rule out the possibility of change across the lifespan (e.g. Sankoff \& Blondeau 2007).

${ }^{13}$ However, this is not the pattern found in Edinburgh (Schleef 2013: 209). This may be due to the influence English speakers exert on this variety, which disrupts the faithful replication of constraints as opposed to indicating a different source for this feature (e.g. Scobbie 1999). 
390), but rather a more local root which subsequently spreads to other environments of use. The hierarchies shown in figure 6 may then be interpreted as traces of the past continuing into the present day, with these traces subsequently being lost in the younger generations as the variant exhibits higher and higher rates of use.

Word-internal onsets are equally interesting in terms of the trajectory of change and comparison with other dialects. This is one of the few contexts which resists glottal replacement in many varieties studied (Docherty et al. 1997: 290).${ }^{14}$ Even in Glasgow, Stuart-Smith (1999: 194) reports 'obligatory' use of [?] in prepausal, and frequent use in prevocalic and intervocalic contexts in working-class speech, but to the best of our knowledge, [?] is not attested in word-internal onset positions. However, glottal replacement is permitted in this context within a number of traditional dialects such as Fife in eastern Scotland, where it is described as "quite normal"15 (Leslie 1983, cited in Harris \& Kaye 1990: 270). Once Buckie is included in this mix, this geographical mapping may further complicate the issue of origins and subsequent development of [?]. If Andrésen's (1968: 18) statement is right, that glottal replacement first appeared in the west of Scotland and spread to the east of Scotland and the far north of England some years later, then why do Fife and Buckie use the variant in onset positions when Glasgow does not? The constraint hierarchies across the generations suggest that onsets are one of the last contexts to 'succumb' to glottal replacement as it has the lowest rates of use across all three generations. Note too that in the younger speakers this context lags behind compared to the increases in other environments. This suggests that onset contexts are most likely a later development in the spread of [?] in these varieties, but how they arise remains unclear.

Whatever its origins, the phonetic details of word-internal onset positions may play a part in its lower rates of use. Tollfree (1999: 183) suggests that in general more prominent syllables tend to block glottal replacement. However, certain exceptions to this exist, namely the teen numerals (e.g. nineteen) and the lexical item sometimes. In Buckie we find a range of permissible onset environments for glottal replacement as in $(10 \mathrm{a}-\mathrm{d})$ :

(10) (a) And I mind some[?]imes three ice creams vans in the street. (Lana, middle-aged female)

(b) That was at seven[?] een year old. (Donald, older male)

(c) Black and white car[?]oonii. (Sandy, middle-aged male)

(d) ....in that rou[?]ine. (Donald, older male)

\footnotetext{
${ }^{14}$ Although Tollfree (1999: 183) does report t-glottalling in onset contexts in particular prosodic environments (swear to god) and its use in the lexical item sometimes.

${ }^{15}$ Furthermore, a different but related phenomenon glottalisation (or glottal reinforcement) is also permitted in foot-initial contexts in Tyneside (Docherty et al. 1997: 290). There may be similarities between these processes but more research is necessary to establish a direct link.
} 
While Buckie may permit a broader range of environments compared to most other dialects, it would appear that the specific patterning can still be linked to the relative prominence of the syllable in question. Gimson (1965: 219) outlines a range of factors which may contribute to a sound's prominence and highlights that 'certain English phonemes are particularly associated with unaccented situations'. Specifically, he observes that while the vowels / $/, \mathrm{I}, \mathrm{\mho} /$ 'may receive full accentual prominence, [they] have a high frequency of occurrence in unaccented syllables. The other English vowels may also occur in syllables which do not receive the primary accent but they may be associated in the speaker's and listener's minds with some degree of secondary accent.' The relationship between prominence and quality may help to explain the patterning of this environment in Buckie. For instance, glottal replacement was not permitted following an unaccented syllable containing a typically unaccented vowel e.g. the /I/ in guitar, but is permitted following an unaccented syllable containing a typically accented vowel e.g. the /u/ or /a/ in routine or cartoon, etc. This is presumably because the second syllable in words like routine and cartoon is relatively less prominent than that of guitar. So while Buckie may be different from the majority of other dialects studied to date, the prominence hierarchy is still present. However, the exact threshold may be slightly higher than most dialects, as summarised below.

Majority of dialects:

Gui[?]ar* $>$ rou[?]ine* $>$ car[?]oon* $>$ some[?]imes $>$ nine[?]een

Buckie:

Gui[?]ar* $>$ rou[?]ine $>$ car[?]oon $>$ some[?]imes $>$ nine[?]een

Whether the trajectory of change in other dialects involves a spread of [?] to include these environments is a question for future research, but for now we note Docherty et al.'s (1997: 290) observation that particular contexts should not be ruled out as permitting glottal replacement even if they only do so very infrequently.

The Coda\#Pause environment also provides an interesting comparison with other varieties. In the majority of studies, coda pause contexts favour glottal replacement in comparison to word medial contexts (see section 2.1). However, in Buckie, this context disfavours [?] across all age groups. How can this be explained? In their study of Newcastle, Docherty \& Foulkes (1999: 62) find that glottal variants 'are almost categorically prohibited in pre-pausal position'. Following Local, Kelly \& Wells (1986: 416), they explain the rarity of glottal replacement in this environment as 'best understood in relation to conversational structure or utterance structure' where a nonglottalised released [ $\mathrm{t}$ ] signals the end of a conversational turn in Tyneside English (Docherty et al. 1997: 294). In other words, variant choice may be governed by pragmatic factors. To test whether the current data also show this constraint we divided the data into turn-internal pause versus turn-final pause contexts of use to see whether the latter had lower rates of [?] in line with the data in Tyneside. Figure 12 shows the results. 


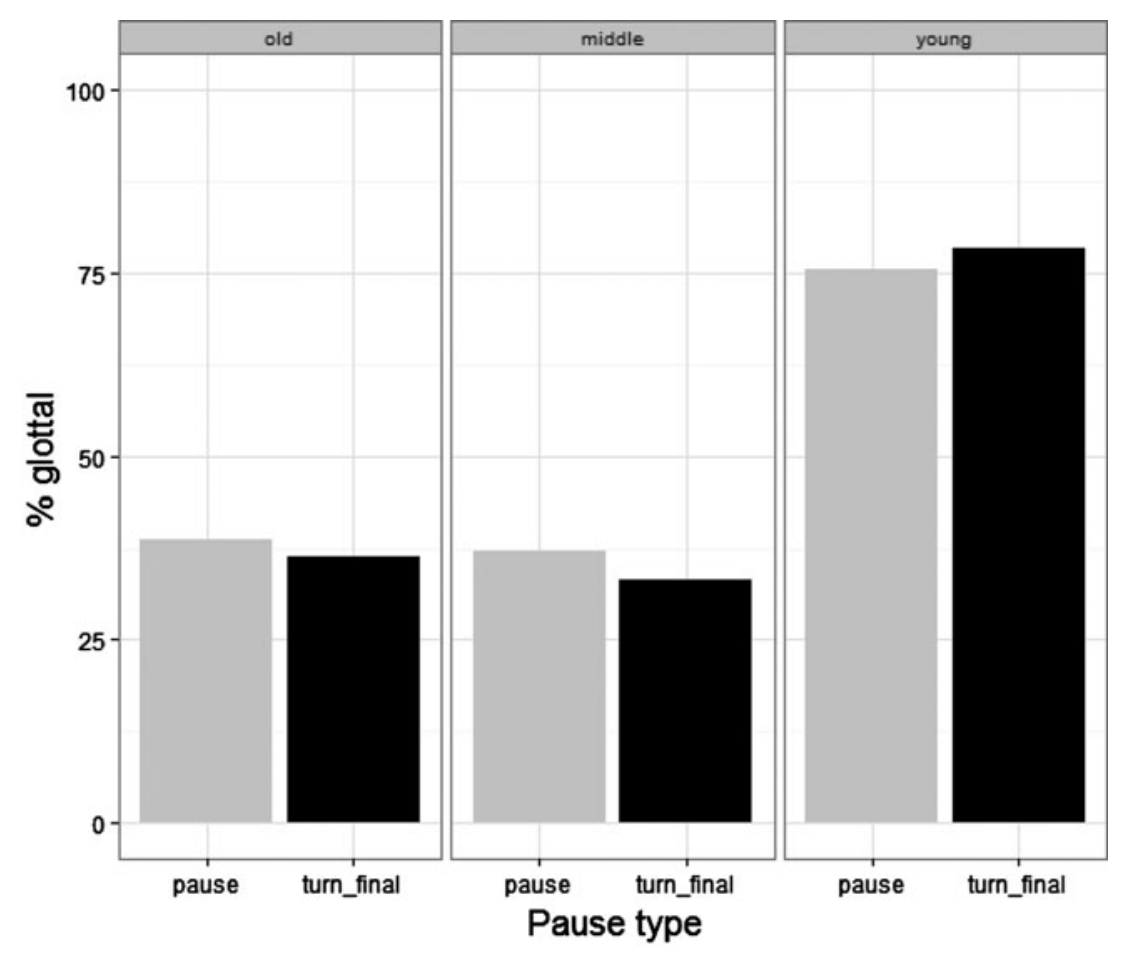

Figure 12. Glottal replacement by age and pause type

Figure 12 suggests that there is no difference between pause and turn final contexts for any age group and further chi-square tests revealed there was no significant association between the type of pause and rates of glottal replacement across all age cohorts (older: $\mathrm{p}=.81$; middle-aged: $\mathrm{p}=.59$; young: $\mathrm{p}=.64$ ). In this dialect, the constraint is simply pause, no matter what type. This may be one of the 'regional particularities' (Schleef 2013: 203) which differentiates the Buckie dialect from most others studied, where a pause is signalled by the now marked form in the dialect - a fully released $[\mathrm{t}] .^{16}$

While there are clear linguistic constraints on the use of [?], our analysis revealed a number of social influences at work in the rise of this variant. The first important finding is that all individuals participate in the change (see figure 4). Moreover, there is evidence of 'early adopters' of the innovative form - Joel and Donald who are differentiated at the earlier stages of change by their extremely high rates

\footnotetext{
${ }^{16}$ We also differentiated the discourse marker right (You saw her, right?) but found it had the same rates of use as the more general pause/turn final contexts, thus was considered in the overall rates.
} 
of [?]. ${ }^{17}$ However, in the course of the rapid rise of this form there is a noted attenuation of within-group differences across the generations: in the older speakers, the difference between the lowest and highest users is 66 per cent, in the middle-aged 44 per cent but only 24 per cent for the youngest cohort. As the form increases in use, the differences between individuals decrease as the change progresses towards the end point of the s-shaped curve. At the same time, the wider social categories also undergo a levelling of differences, namely gender and addressee, as detailed below.

With respect to gender, previous research demonstrates that in working-class speech, males lead the change in the rise of the non-standard variant (see section 2.2). This is perhaps not surprising: the historical record suggests that for many decades this has been a highly stigmatised form, thus one to be avoided by females. However, previous research also suggests that as the change progresses, gender differences neutralise. This is exactly what we see in the current data, where the mixed-effects models in table 3 show a statistically significant effect for gender in the older and middle-aged cohort, but none for the younger age group.

A neutralisation of the insider/outsider constraint is also found over time: older speakers show a significant difference according to addressee, but the middle-aged and younger speakers do not. In addition, participants in the older cohort have higher rates of the non-standard variant when talking to the community outsider and this is true for individuals within this group. These results may pinpoint the generation of flux in the system: as glottal replacement has not as yet laid down a solid foundation in this older generation, it is more 'unstable' and thus more susceptible to other influences. One possible outcome of this is accommodation (Trudgill 1986: 39) as demonstrated by our results where certain speakers adjust their use to accommodate to the outsider's higher rates. We further hypothesise that as the rates of [?] increase in the community, no such accommodation is warranted as speakers use [?] as much or even more than the outsider. This is signalled by the largely flat lines across addressee, for example, most of the younger cohort. What this means more generally is that processes of accommodation to speakers and/or varieties may be implicated in the rise of glottal replacement in the manner described more generally by Trudgill (1986: 42): 'the geographical diffusion of linguistic forms takes place, for the most part, when face-to-face interaction between speakers from different areas happens sufficiently frequently for accommodation to become permanent, and on a sufficiently large scale for considerable numbers of speakers to be involved.'

\section{Conclusion}

Traditionally, glottal replacement has been one of the most stigmatised variants in the British Isles. Despite this, its rise is unrivalled in terms of speed and scope

\footnotetext{
${ }^{17}$ A possible explanation for this is that both men worked in jobs that required them to travel, hence they may have had more diffuse networks than other individuals of the same age.
} 
of its spread. This in-depth analysis of one dialect aimed to shed light on the trajectory of change from new and vigorous to completed, and brings us full circle back to the original question of origins and development of glottal replacement more generally. Our analysis has shown that glottal replacement has been around in this peripheral dialect for at least three generations, and has spread rapidly in that time. The linguistic patterning that we have uncovered indicates that it is very unlikely that the source of [?] is London or indeed Glasgow. It looks more akin to the patterns found in northeastern varieties such as Tyneside and Fife, although this is not to rule out the influence of other varieties in the spread of this form. In the end, our current understanding of the complexities of where glottal replacement arose, and how it subsequently spread, is perhaps best summed up by Trudgill (2008: 9) thus: 'a relatively recent phenomenon, perhaps no more than 150 years old, with its origins in lower sociolects in London and/or Glasgow and/or East Anglia'. Analyses of other dialect areas may contribute further to our understanding of the 'and/or' in the trajectory of this iconic variable through time and space.

Authors' addresses:

English Language and Linguistics

University of Glasgow

12 University Gardens

Glasgow G12 8QH

$U K$

Jennifer.Smith@glasgow.ac.uk

Division of Modern Languages

Faculty of Humanities

University of Southampton

Avenue Campus

Highfield

Southampton SO17 1BF

$U K$

S.E.M.Holmes-Elliott@soton.ac.uk

\section{References}

Andrésen, Bjørn Stålhane. 1968. Pre-glottalization in English standard pronunciation. Oslo: Norwegian Universities Press.

Baranowski, Maciej \& Danielle Turton. 2014. Linguistic and social constraints on consonantal variation in Manchester English. Paper presented at Methods in Dialectology XV, University of Groningen.

Beal, Joan C. 2014. English in modern times. London: Routledge.

Bell, Allan. 1984. Language as audience design. Language in Society 13, 145-204.

Bell, A. M. 1860. The elocutionary manual. Cited in Andrésen (1968). 
Boudahmane, Karim, Mathieu Manta, Fabien Antoine, Sylvain Galliano \& Claude Barras.

2008. Transcriber - Copyright (C) 1998-2008, DGA http://trans.sourceforge.net/

Coupland, Nikolas. 1984. Accommodation at work: Some phonological data and their implications. International Journal of the Sociology of Language 46, 49-70.

Devitt, Amy J. 1989. Standardizing written English: Diffusion in the case of Scotland 1520-1659. Cambridge: Cambridge University Press.

Docherty, Gerard J. \& Paul Foulkes. 1999. Derby and Newcastle: Instrumental phonetics and variationist studies. In Foulkes \& Docherty (eds.), 47-71.

Docherty, Gerard J., Paul Foulkes, James Milroy, Lesley Milroy \& David Walshaw. 1997. Descriptive adequacy in phonology: A variationist perspective. Journal of Linguistics 33(2), 275-310.

Douglas-Cowie, E. 1978. Linguistic code-switching in a Northern Irish village. In Peter Trudgill (ed.), Sociolinguistic patterns in British English, 37-51. London: Edward Arnold.

Drummond, Rob. 2011. Glottal variation in /t/ in non-native English speech: Patterns of acquisition. English World-Wide 32(3), 280-308.

Fabricius, Anne H. 2000. T-glottalling between stigma and prestige: A sociolinguistic study of modern RP. Unpublished PhD thesis, Copenhagen Business School.

Fabricius, Anne H. 2002. Ongoing change in modern RP: Evidence for the disappearing stigma of t-glottalling. English World-Wide 23(1), 115-36.

Flynn, Nicholas. 2012. A sociophonetic study of Nottingham speakers. Unpublished $\mathrm{PhD}$ thesis, University of York.

Foulkes, Paul \& Gerard J. Docherty (eds.). 1999. Urban voices: Accent studies in the British Isles. London: Arnold.

Giles, Howard. 1973. Accent mobility: A model and some data. Anthropological Linguistics $15,87-105$.

Gimson, Alfred C. 1965. An introduction to the pronunciation of English. London: Arnold.

Guy, Gregory. 1980. Variation in the group and the individual: The case of final stop deletion. In William Labov (ed.), Locating language in time and space, 1-36. New York: Academic Press.

Harris, John \& Jonathan Kaye. 1990. A tale of two cities: London glottaling and New York tapping. Linguistic Review 7, 251-74.

Holmes, Janet. 1994. New Zealand flappers: An analysis of T voicing in New Zealand English. English World-Wide 15, 195-224.

Hughes, Arthur, Peter Trudgill \& Dominic J. L. Watt. 2012. English accents and dialects: An introduction to social and regional varieties of English in the British Isles, 5th edn. London: Hodder Education.

Johnson, Daniel E. 2009. Getting off the GoldVarb standard: Introducing Rbrul for mixed-effects variable rule analysis. Language and Linguistics Compass 3(1), 359-83.

Jones, Daniel. 1956. The pronunciation of English, 4th edn. Cambridge: Cambridge University Press (1st edn 1909).

Kerswill, Paul E. 2003. Dialect levelling and geographical diffusion in British English. In David Britain \& Jenny Cheshire (eds.), Social dialectology: In honour of Peter Trudgill, 223-43. Amsterdam: John Benjamins.

Labov, William. 1966. The stratification of English in New York City. Washington, DC: Center for Applied Linguistics.

Labov, William. 1972. Sociolinguistic patterns. Philadelphia: University of Pennsylvania Press. 
Labov, William. 1984. Field methods of the project on linguistic change and variation. In John Baugh \& Joel Sherzer (eds.), Language in use: Readings in sociolinguistics, 28-53. Englewood Cliffs, NJ: Prentice Hall.

Labov, William. 2001. Principles of linguistic change, vol. 2: Social factors. Oxford: Blackwell.

Leslie, David. 1983. Left capture and British voiceless stop allophony. Paper presented at the 19th Congress of the International Association of Logopaedics and Phoniatrics, University of Edinburgh, 1983. Cited in Harris \& Kaye 1990.

Llamas, Carmen. 2007. 'A place between places': Language and identities in a border town. Language in Society 36(4), 579-604.

Local, John K., John Kelly \& William H. K. Wells. 1986. Towards a phonology of conversation: Turn-taking in Tyneside. Journal of Linguistics 22, 411-17.

Macaulay, Ronald K. S. 1977. Language, social class and education: A Glasgow study. Edinburgh: Edinburgh University Press.

Macaulay, Ronald K. S. 1991. Locating dialect in discourse: The language of honest men and bonnie lasses in Ayr. Oxford: Oxford University Press.

Macaulay, Ronald K. S. \& Gavin D. Trevelyan. 1973. Language, education and employment in Glasgow. Final report to the SSRC.

Marshall, Jonathan. 2001. The sociolinguistic status of the glottal stop in Northeast Scots. Reading Working Papers in Linguistics 5, 49-65.

Mathisen, Anne Grethe. 1999. Sandwell, West Midlands: Ambiguous perspectives on gender patterns and models of change. In Foulkes \& Docherty (eds.), 107-23.

Mees, Inger M. 1987. Glottal stop as a prestigious feature in Cardiff English. English World-Wide 8, 25-39.

Mees, Inger M. \& Beverley Collins. 1999. Cardiff: A real-time study of glottalisation. In Foulkes \& Docherty (eds.), 185-202.

Milroy, Lesley. 2007. Off the shelf or under the counter? On the social dynamics of sound changes. In C. Cain \& G. Russom (eds.), Studies in the history of the English language, vol. III: Managing chaos: Strategies for identifying change in English. Berlin: Walter de Gruyter

Milroy, James, Lesley Milroy, Sue Hartley \& David Walshaw. 1994. Glottal stops and Tyneside glottalization: Competing patterns of variation and change in British English. Language Variation and Change 6, 327-57.

Orton, Harold, Stewart Sanderson \& John Widdowson. 1978. The linguistic atlas of England. London: Croon Helm.

Reid, Euan C. 1978. Social and stylistic variation in the speech of children: Some evidence from Edinburgh. In Peter Trudgill (ed.), Sociolinguistic patterns in British English, 158-71. London: Edward Arnold.

Richards, Hazel M. 2008. Mechanisms, motivations and outcomes of change in Morley (Leeds) English. Unpublished PhD thesis, University of York.

Romaine, Suzanne. 1975. Linguistic variability in the speech of some Edinburgh schoolchildren. Unpublished MLitt thesis, University of Edinburgh.

Romaine, Suzanne \& Euan C. Reid. 1976. Glottal sloppiness? A sociolinguistic view of urban speech in Scotland. Teaching English 9, 12-17.

Sankoff, Gillian \& Hélène H. Blondeau, 2007. Language change across the lifespan: /r/ in Montreal French. Language 83(3), 560-88.

Schleef, Erik. 2013. Glottal replacement of /t/ in two British capitals: Effects of word frequency and morphological compositionality. Language Variation and Change 25(2), 201-23. 
Scobbie, James M., Nigel Hewlett \& Alice Turk. 1999. Standard English in Edinburgh and Glasgow: The Scottish vowel length rule revealed. In Paul Foulkes \& Gerry Docherty (eds.), Urban voices: Variation and change in British accents, 230-45. London: Arnold.

Shockey, Linda. 2003. Sound patterns of spoken English. Oxford: Blackwell.

Smith, Jennifer. 2001a. Negative concord in the Old and New World: Evidence from Scotland. Language Variation and Change 13(2), 109-34.

Smith, Jennifer. 2001b. Ye ø na hear that kind o' things: Negative do in Buckie. English World-Wide 21(2), 231-59.

Smith, Jennifer. 2004. Accounting for vernacular features in a Scottish dialect: Relic, innovation, analogy and drift. In Christian Kay, Simon Horobin \& Jeremy Smith (eds.), New perspectives on English historical linguistics, vol. 1: Syntax and morphology, 173-193. Amsterdam: John Benjamins.

Smith, Jennifer. 2005. The sociolinguistics of contemporary Scots: Evidence from one dialect. In John M. Kirk \& Donall Ó Baoill (eds.), Legislation, literature and sociolinguistics: Northern Ireland, the Republic of Ireland, and Scotland, 112-25. Belfast: Cló Ollscoil na Banríona.

Smith, Jennifer. 2013-16. One speaker two dialects: Bidialectalism across the generations in a Scottish community. Economic and Social Research Council grant no. ES/K000861/1.

Smith, Jennifer, Mercedes Durham \& Liane Fortune. 2007. Community, caregiver and child in the acquisition of variation in a Scottish dialect. Language Variation and Change 19(1), 63-99.

Smith, Jennifer, Mercedes Durham \& Hazel Richards. 2013. The social and the linguistic in the acquisition of sociolinguistic variation. Linguistics 51(2), 285-324.

Smith, Jennifer \& Sophie Holmes-Elliott. 2015. Parenting style: From preschool to preadolescence in the acquisition of variation. Paper presented at NWAV 44, University of Toronto.

Smith, Jennifer \& Sali A. Tagliamonte, 1998. We was all thegither, I think we were all thegither. World Englishes 17(2), 105-26.

Stoddart, Jana, Clive Upton \& J. D. A. Widdowson. 1999. Sheffield dialect in the 1990s: Revisiting the concept of NORMs. In Foulkes \& Docherty (eds.), 72-89.

Straw, Michelle \& Peter L. Patrick. 2007. Dialect acquisition of glottal variation in /t/:

Barbadians in Ipswich. Language Sciences 29, 385-407.

Stuart-Smith, Jane. 1999. Glottals past and present: A study of T-glottalling in Glaswegian. Leeds Studies in English 30, 181-204.

Sweet, Henry. 1908. The sounds of English. Oxford. Oxford University Press.

Tollfree, Laura. 1999. South East London English: Discrete versus continuous modelling of consonantal reduction. In Foulkes \& Docherty (eds.), 163-84.

Trudgill, Peter. 1974. The sociolinguistic differentiation of English in Norwich. Cambridge: Cambridge University Press.

Trudgill, Peter. 1986. Dialects in contact. Oxford: Blackwell.

Trudgill, Peter. 1988. Norwich revisited: Recent changes in an English urban dialect. English World-Wide 9, 33-49.

Trudgill, Peter. 1999. Norwich: Endogenous and exogenous change. In Foulkes \& Docherty (eds.), 124-40.

Trudgill, Peter. 2008. The historical sociolinguistics of elite accent change: Why RP is not disappearing. Studio Anglica Posnaniensia 44, 1-12.

Watt, Dominic \& Lesley Milroy. 1999. Patterns of variation and change in three Newcastle vowels: Is this dialect levelling? In Foulkes \& Docherty (eds.), 26-46. 
Weinreich, Uriel, William Labov \& Marvin Herzog. 1968. Empirical foundations for a theory of language change. In Winfred P. Lehmann \& Yakov Malkiel (eds.), Directions for historical linguistics: A symposium, 97-193. Austin, TX: University of Texas Press.

Wells, John C. 1982. Accents of English, vol. 1: An introduction. Cambridge: Cambridge University Press.

Wells, John C. 1997. What's happening to Received Pronunciation? English Phonetics (English Phonetic Society of Japan) 1, 13-23.

Wells, John C. 2014. Sounds interesting: Observations on English and general phonetics. Cambridge: Cambridge University Press.

Williams, Ann \& Paul Kerswill. 1999. Dialect levelling: Change and continuity in Milton Keynes, Reading and Hull. In Foulkes \& Docherty (eds.), 141-62.

Wolfram, Walt. 1993. Identifying and interpreting variables. In Dennis R. Preston (ed.), American dialect research, 193-222. Amsterdam: John Benjamins.

Wright, Joseph. 1905. The English dialect grammar. Oxford: Henry Frowde. 


\section{Appendix}

Table A1. Fully articulated coding system for linguistic context

\begin{tabular}{|c|c|c|c|}
\hline Syllabic context & Preceding & Following & Example \\
\hline \multirow[t]{8}{*}{ Coda } & \multirow[t]{2}{*}{ vowel } & vowel & $\begin{array}{l}\text { fae here, go out and that so I just } \\
\text { bide out the way } \\
\text { if you like a bit off of one dress you } \\
\text { do na like the other bit }\end{array}$ \\
\hline & & pause & $\begin{array}{l}\text { which kept them afloat } \\
\text { ken five o'clock in the evening 'til } \\
\text { nine o'clock at night }\end{array}$ \\
\hline & \multirow[t]{2}{*}{$/ 1 /$} & vowel & $\begin{array}{l}\text { pulled down and re-built again } \\
\text { I could na really download nothing } \\
\text { so I solt it }\end{array}$ \\
\hline & & pause & $\begin{array}{l}\text { market for about three year. Can na } \\
\text { get it selt }\end{array}$ \\
\hline & \multirow[t]{2}{*}{$/ \mathrm{n} /$} & vowel & $\begin{array}{l}\text { So, she's went about it the alternate } \\
\text { route } \\
\text { just think like of the amount of stuff } \\
\text { you could get accused of }\end{array}$ \\
\hline & & pause & on a a mediterranean cruise at the \\
\hline & \multirow[t]{2}{*}{$/ \mathrm{r} /$} & vowel & $\begin{array}{l}\text { they were in a restaurant } \\
\text { they're never short of a buck or two } \\
\text { First port of call, Honolulu }\end{array}$ \\
\hline & & pause & $\begin{array}{l}\text { mind you we were all feart } \\
\text { and they got off the ship at one port }\end{array}$ \\
\hline \multirow[t]{4}{*}{ Ambi } & \multirow[t]{3}{*}{ vowel } & vowel & $\begin{array}{l}\text { the better choice-you did nt have to } \\
\text { take the top rota } \\
\text { acrobatics and stuff }\end{array}$ \\
\hline & & $/ \mathrm{n} /$ & $\begin{array}{l}\text { queer grub they're getting } \\
\text { have all went offshore or gotten jobs } \\
\text { a- ashore }\end{array}$ \\
\hline & & $/ 1 /$ & $\begin{array}{l}\text { Little bean neepies } \\
\text { so she's kind of trying to rattle at } \\
\text { that as well }\end{array}$ \\
\hline & $/ \mathrm{n} /$ & vowel & $\begin{array}{l}\text { eh it's winter time I should say } \\
\text { twenty-odd years now, she's been } \\
\text { teaching }\end{array}$ \\
\hline
\end{tabular}


Table A1. Continued

\begin{tabular}{|c|c|c|c|}
\hline Syllabic context & Preceding & Following & Example \\
\hline & & $/ 1 /$ & $\begin{array}{l}\text { That's mental, like } \\
\text { now he's a gentleman you ken } \\
\text { him }\end{array}$ \\
\hline & & $/ \mathrm{n} /$ & $\begin{array}{l}\text { I think I'm just like wanting to } \\
\text { painting the ceilings, painting the } \\
\text { walls, painting doors }\end{array}$ \\
\hline & $/ 1 /$ & vowel & $\begin{array}{l}\text { This was the Norwegian Royalty } \\
\text { The shelter got hit, and all her } \\
\text { family were killed }\end{array}$ \\
\hline & $/ \mathrm{r} /$ & vowel & $\begin{array}{l}\text { but folk are starting to get mega } \\
\text { annoyed } \\
\text { a hundred and forty down to like } \\
\text { sixty five or something }\end{array}$ \\
\hline & & $/ \mathrm{n} /$ & And tartan denim jeans \\
\hline & & & $\begin{array}{l}\text { You had to have your supper at a } \\
\text { certain time and }\end{array}$ \\
\hline & & $/ 1 /$ & Turtle \\
\hline \multirow[t]{4}{*}{ Onset } & & & $\begin{array}{l}\text { sometimes there is na answers } \\
\text { for everything }\end{array}$ \\
\hline & & & $\begin{array}{l}\text { Sometimes, yeah, like sometimes } \\
\text { fann I sleep }\end{array}$ \\
\hline & & & $\begin{array}{l}\text { 'Cause this was nineteen oh } \\
\text { seven, this ain }\end{array}$ \\
\hline & & & $\begin{array}{l}\text { he left the school at thirteen } \\
\text { got knocked out of a routine, you } \\
\text { were oh- }\end{array}$ \\
\hline
\end{tabular}

